\title{
Article
}

\section{Multi-Leaf Stone Masonry Walls in Egypt: A Legend}

\author{
Osama Amer ${ }^{1, * \mathbb{D}}$, Danila Aita ${ }^{2}$, Ezzeldin k. Mohamed ${ }^{3}$, Akram Torky ${ }^{4}$ and Ashraf Shawky ${ }^{4}$ \\ 1 Department of Conservation, Cairo University, Giza 12613, Egypt \\ 2 Architecture and Design Department, University of Genoa, 16123 Genoa, Italy; danila.aita@edu.unige.it \\ 3 National Water Research Centre, Construction Research Institute, Shoubra El-Kheima 13621, Egypt; \\ ezzeldin_kamel@nwrc.org.eg \\ 4 Department of Civil Engineering, Faculty of Engineering, Cairo University, Giza 12613, Egypt; \\ amtorkey@eng.cu.edu.eg (A.T.); ashraf.shawky@mentor-mcg.com (A.S.) \\ * Correspondence: osama_amer@cu.edu.eg
}

Citation: Amer, O.; Aita, D.;

Mohamed, E.k.; Torky, A.; Shawky, A Multi-Leaf Stone Masonry Walls in Egypt: A Legend. Heritage 2021, 4, 2763-2791. https://doi.org/10.3390/ heritage 4040156

Academic Editor: Giuliana Cardani

Received: 17 August 2021

Accepted: 24 September 2021

Published: 28 September 2021

Publisher's Note: MDPI stays neutral with regard to jurisdictional claims in published maps and institutional affiliations.

\begin{abstract}
Multi-leaf stone masonry walls are a typical construction technique in architectural heritage in Egypt. The assessment, modeling, and strengthening of historic masonry walls of multi-leaf systems essentially require suitable knowledge of their construction technology, typology, geometrical characteristics, and the properties of their components. Within the current research project, a comprehensive structural survey of multiple-leaf walls of medieval historic buildings in Cairo was performed. The observation and statistical analyses allowed characterization of the transversal section of the surveyed walls, as well as examination and identification of the construction materials and techniques. The slenderness ratios of this type of wall, its blocks' dimensions, the utilized connectivity between the inner and outer leaves, and leaves ratio were also investigated. Three construction hypotheses of multiple-leaf stone masonry walls are presented considering weak, thick, and monolithic core infill layers. The study's objectives were to enlarge the knowledge of typology, morphology, and construction materials used in three-leaf masonry walls and provide a proper characterization as a prerequisite for determining the most suitable materials and techniques for further strengthening interventions.
\end{abstract}

Keywords: historic constructions; three-leaf masonry walls; field survey; architectural heritage; construction history

\section{Introduction}

Multi-leaf masonry walls (MLMW) constitute the construction typology most widely adopted in historic buildings worldwide. They are found, for example, in Roman buildings [1]. Most complex historic constructions in Egypt present bearing structural elements built up adopting the multiple-leaf masonry technique, which gives a non-homogeneous structural element. This building technology is around 4000 years old. It exists in a variety of forms [2]: it usually was used as vertical structural elements in historic houses, public buildings, religious constructions, and hydraulic structures. In more recent years, this type of wall was also adopted for piers in road and railway bridges [3-5].

Multiple-leaf stone masonry walls are characterized by different construction techniques and typologies that have gradually changed from those with weak and cohesionless inner core layers to the fixed rubble-core masonry. Furthermore, the inner and outer layers could be strongly bonded together utilizing transversal bond elements; in some cases, the separated behavior of each layer is attained due to the absence of the shear keys/through stones between the leaves (walls with straight collar joints) [6-8]. Many structural problems are encountered in these structures, due to a weak internal layer, mortar deterioration, and lack of connection between the leaves [8-10] (see Figure 1). These problems can lead to the development of high stresses and the separation of the leaves and, consequently, affect the overall stability of the wall [11,12]. 


\section{$a$}

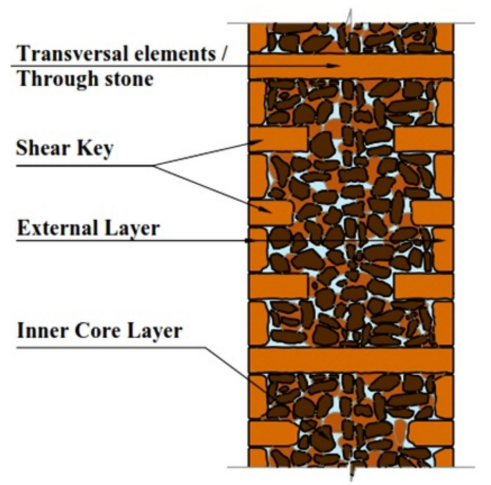

b

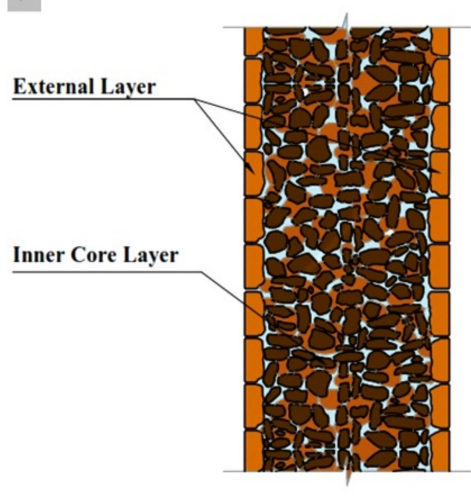

Cross-Section

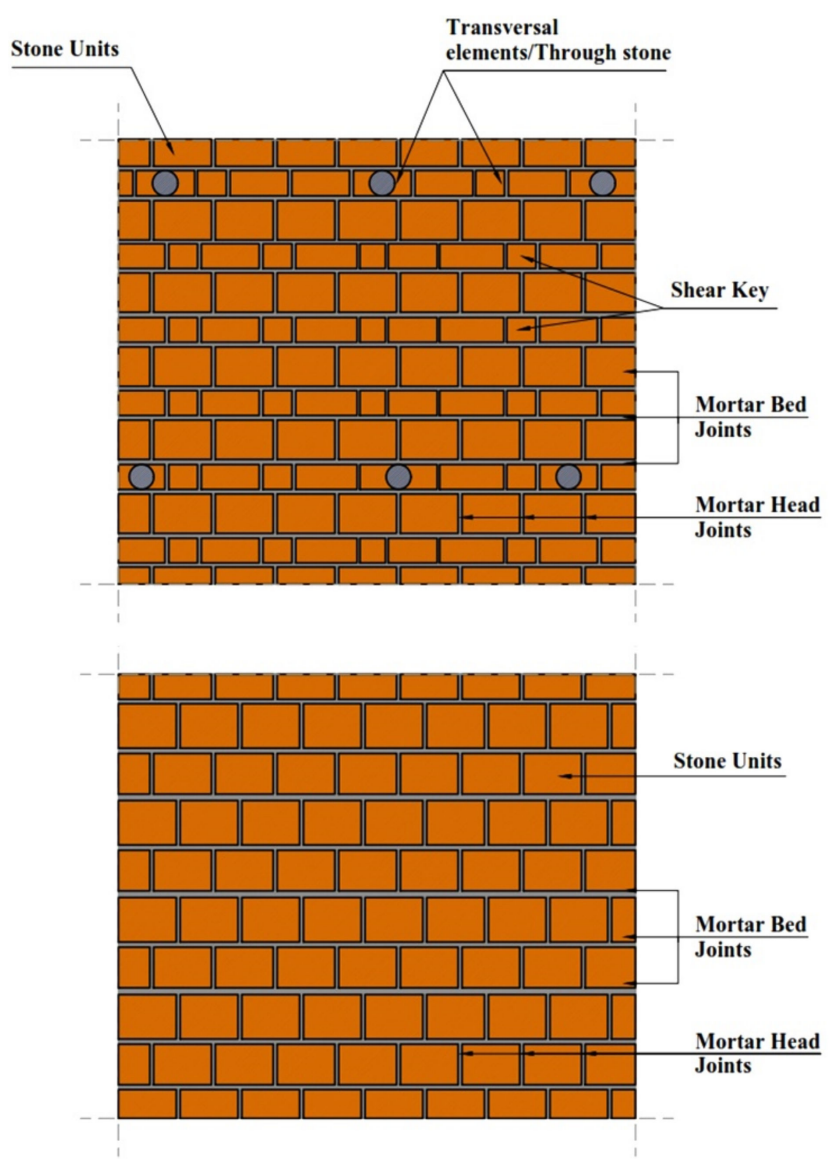

Elevation

Figure 1. Common typologies of the of multiple-leaf stone masonry walls with (a) keyed and (b) straight collar joints.

Several monuments consisting of multi-leaf walls have experienced excessive damage and failure caused by high compressive and shear loads (e.g., Bab Qaytbay, Takiyya Ibrahim al-Kulshani, Wakala al-Sultan Qaytbay, among others). However, structural interventions can be properly accomplished in this type of construction if the properties and the existing internal defects or damage are properly identified. In addition, retrofitting/strengthening techniques-including grout injection where mortar is heavily deteriorated, mortar repointing of the external layers of the joints, and establishment of proper connection between the leaves-often alter the properties of the wall, increasing the stiffness of the inner layer and the wall itself and, thus, modifying its response to different loading conditions [13-18]. Undoubtedly, these interventions require thorough and accurate studies of the mechanical response of this type of construction before and after interventions to achieve the greatest possible compatibility.

Recently, some scholars have studied the mechanical behavior of the multi-leaf masonry walls, by examining material discretization and the role of each leaf in the global behavior of the wall [7,19-25]. Since the activities of old masons strongly depended on the available material near the construction site and on their experience, which was not handed down by written documents, it is not possible to find unified, simple design criteria relating the wall height, thickness, and filling material with reference to the function/type of the structure. Discovering this secret is a challenge. This was the motivation for investigating multi-leaf walls in historic constructions in Egypt during Fatimid, Ayyubid, Mamluk, and Othman eras and the development of this construction technique during the Mohamed Ali period and the British colony years. 
In order to accurately assess the structural performance of this particular type of historical masonry wall under various types of loads, it is necessary to adequately understand the structure, its typology, its behavior and response, as well as the constituent materials and their mechanical characteristics. Moreover, the study of the multiple-leaf masonry wall sections can be significant with respect to structural analysis, by providing essential input data concerning wall morphology and geometry, which are useful for adopting appropriate mathematical models, formulating valid hypotheses on mechanical stability, and verifying possible failure mechanisms. Correspondingly, it is imperative to follow a methodology that includes a detailed survey and diagnosis to obtain reliable documentation corroborating the selection of the correct and effective intervention technique fitting best with the strengthening requirements. As a result, a detailed understanding of the morphology, typology, and utilized construction techniques of this common type of wall is necessary to minimize restoration interventions for strengthening or repair. This is the point of view from which the present paper developed some reflection about the construction aspects of the multiple-leaf stone masonry walls of the medieval constructions of architectural heritage in Egypt.

A systematic survey concerning the evolution of building materials and construction technology of multiple-leaf masonry load-bearing walls in Cairo during different medieval periods was carried out to analytically determine the construction techniques and structural characteristics, not clearly inferable from the literature. A total of thirty-three historic buildings in Cairo dating to different centuries of the Middle Ages and at various locations were surveyed. Various samples of stone blocks and mortars were studied for material characterization, while the research sources provided historical documentation on some surveyed buildings. The survey data are listed according to the historical period, including building name, type, period, current condition, usage, monument registration number $(\mathrm{RN})$, and geometrical data of the multiple-leaf masonry walls. For further historical research on the surveyed building, the reader is referred to the following studies [26-42]. The monuments surveyed during the present study, summarized in Table 1 and Figure 2, included the following: two masjids, two main gates, four towers, five mausoleums, eleven complex buildings (i.e., madrasa, khanqah, sabil-kuttab, etc.), four palaces, and five other ruined monuments. 


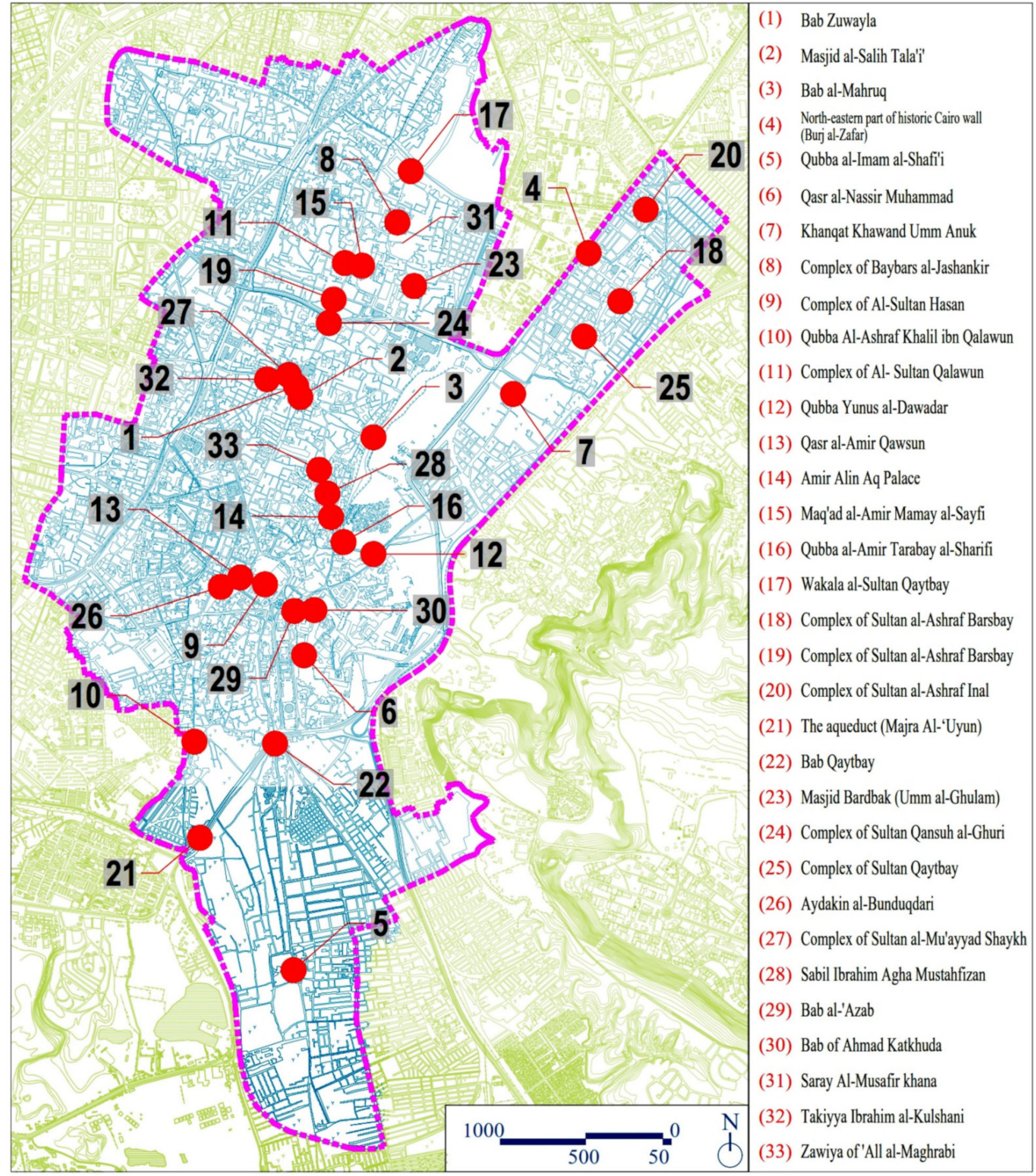

Figure 2. Locations of the surveyed buildings in historic Cairo. 
Table 1. Summary of the conducted field surveyed.

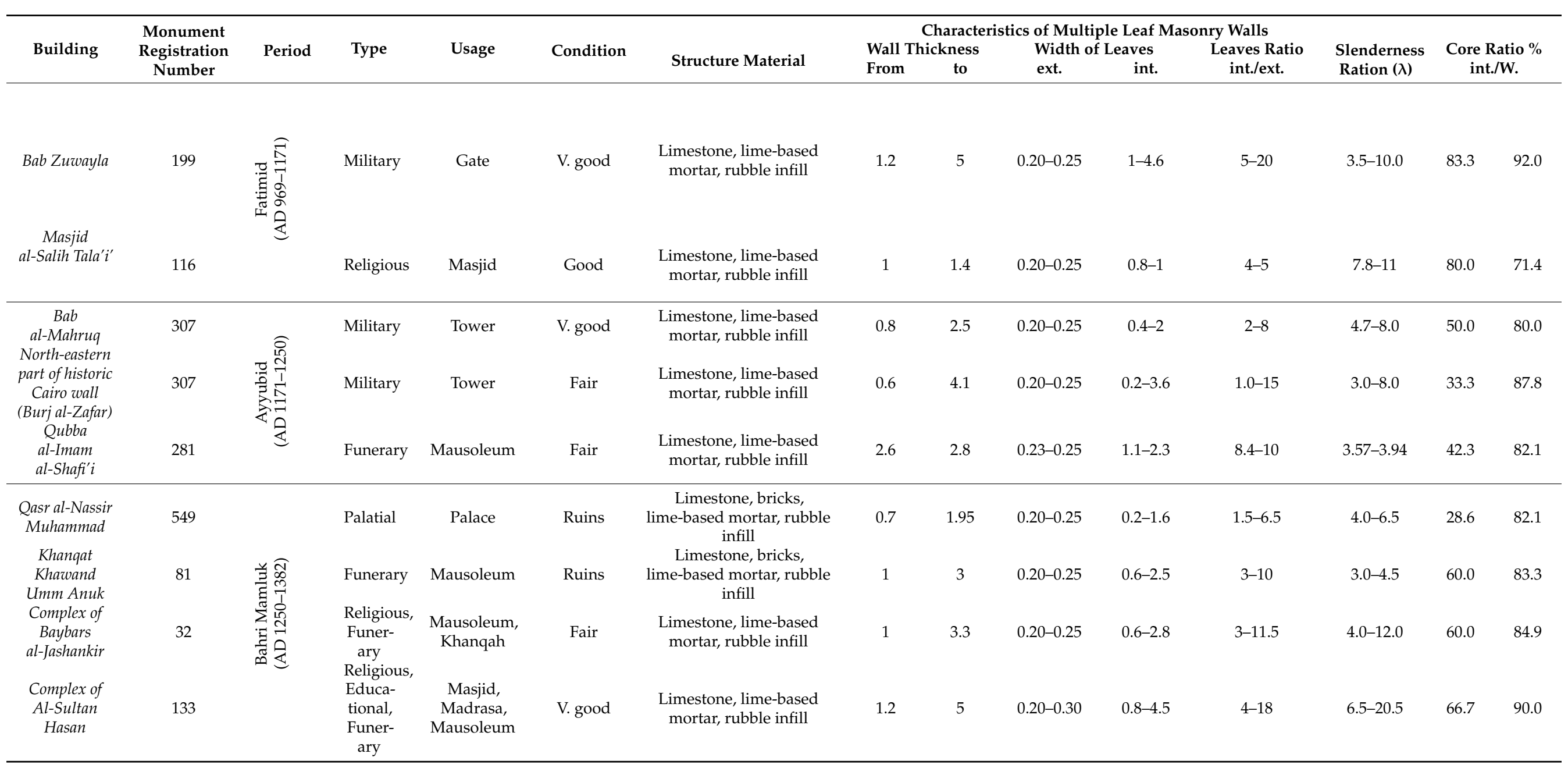


Table 1. Cont.

\begin{tabular}{|c|c|c|c|c|c|c|c|c|c|c|c|c|c|c|}
\hline \multirow{2}{*}{$\begin{array}{l}\text { Building } \\
\text { Qubba }\end{array}$} & \multirow{2}{*}{$\begin{array}{l}\text { Monument } \\
\text { Registration } \\
\text { Number }\end{array}$} & \multirow[b]{2}{*}{ Period } & \multirow[b]{2}{*}{ Type } & \multirow[b]{2}{*}{ Usage } & \multirow[b]{2}{*}{ Condition } & \multirow[b]{2}{*}{ Structure Material } & \multicolumn{5}{|c|}{ Characteristics of Multiple Leaf Masonry Walls } & \multirow[b]{2}{*}{$\begin{array}{l}\text { Slenderness } \\
\text { Ration }(\lambda)\end{array}$} & \multirow{2}{*}{\multicolumn{2}{|c|}{$\begin{array}{l}\text { Core Ratio \% } \\
\text { int./W. }\end{array}$}} \\
\hline & & & & & & & $\begin{array}{l}\text { Wall } 1 \\
\text { From }\end{array}$ & $\begin{array}{l}\text { kness } \\
\text { to }\end{array}$ & $\begin{array}{l}\text { Width } \\
\text { ext. }\end{array}$ & $\begin{array}{l}\text { eaves } \\
\text { int. }\end{array}$ & $\begin{array}{l}\text { Leaves Ratio } \\
\text { int./ext. }\end{array}$ & & & \\
\hline $\begin{array}{l}\text { Al-Ashraf } \\
\text { Khalil ibn } \\
\text { Qalawun }\end{array}$ & 275 & & Funerary & Mausoleum & Good & $\begin{array}{l}\text { Limestone, lime-based } \\
\text { mortar, rubble infill }\end{array}$ & 1.4 & 1.9 & $0.20-0.25$ & $1-1.4$ & $5-7$ & $5.3-7.2$ & 71.4 & 73.7 \\
\hline $\begin{array}{l}\text { Complex of Al- } \\
\text { Sultan } \\
\text { Qalawun }\end{array}$ & 43 & & $\begin{array}{l}\text { Educational, } \\
\text { Health- } \\
\text { care, } \\
\text { Reli- } \\
\text { gious }\end{array}$ & $\begin{array}{c}\text { Masjid, } \\
\text { Hospital, } \\
\text { Madrasa }\end{array}$ & V. good & $\begin{array}{l}\text { Limestone, lime-based } \\
\text { mortar, rubble infill }\end{array}$ & 1.2 & 4.8 & $0.20-0.30$ & $0.8-4.3$ & $4-21$ & $4.0-10.5$ & 66.7 & 89.6 \\
\hline $\begin{array}{l}\text { Qubba Yunus } \\
\text { al-Dawadar }\end{array}$ & 139 & & Funerary & Mausoleum & Ruins & $\begin{array}{l}\text { Limestone, lime-based } \\
\text { mortar, rubble infill }\end{array}$ & 0.7 & 1.2 & $0.20-0.25$ & $0.3-0.8$ & $1.5-4$ & - & 42.9 & 66.7 \\
\hline $\begin{array}{l}\text { Qasral-Amir } \\
\text { Qawsun }\end{array}$ & 266 & & Palatial & Palace & Ruins & $\begin{array}{c}\text { Limestone, bricks, } \\
\text { lime-based mortar, rubble } \\
\text { infill }\end{array}$ & 1.1 & 4.4 & $0.20-0.35$ & $0.4-2.2$ & $2-8.5$ & $4.0-11.0$ & 36.4 & 50.0 \\
\hline $\begin{array}{l}\text { Amir Alin Aq } \\
\quad \text { Palace }\end{array}$ & 249 & & Palatial & Palace & Good & $\begin{array}{l}\text { Limestone, bricks, } \\
\text { lime-based mortar, rubble } \\
\text { infill }\end{array}$ & 1.3 & 3 & $0.20-0.25$ & $0.9-2.5$ & $4.5-10$ & $4.0-9.5$ & 69.2 & 83.3 \\
\hline $\begin{array}{l}\text { Maq'ad } \\
\text { al-Amir } \\
\text { Mamay } \\
\text { al-Sayfi }\end{array}$ & 51 & 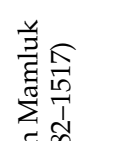 & Residential & Shelter & Good & $\begin{array}{l}\text { Limestone, lime-based } \\
\text { mortar, rubble infill }\end{array}$ & 0.6 & 1.8 & $0.20-0.25$ & $0.2-1.4$ & $1-7.0$ & $10.0-30.0$ & 33.3 & 77.8 \\
\hline $\begin{array}{c}\text { Qubba } \\
\text { al-Amir } \\
\text { Tarabay } \\
\text { al-Sharifi }\end{array}$ & 255 & 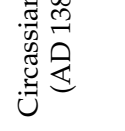 & Funerary & Mausoleum & V. good & $\begin{array}{l}\text { Limestone, lime-based } \\
\text { mortar, rubble infill }\end{array}$ & 0.5 & 1.5 & $0.20-0.25$ & $0.08-1.1$ & $0.35-7.5$ & $2.0-10.5$ & 20.0 & 73.3 \\
\hline
\end{tabular}


Table 1. Cont.

\begin{tabular}{|c|c|c|c|c|c|c|c|c|c|c|c|c|c|c|}
\hline \multirow{3}{*}{$\begin{array}{c}\text { Building } \\
\text { Wakala } \\
\text { al-Sultan } \\
\text { Qaytbay }\end{array}$} & \multirow{3}{*}{$\begin{array}{c}\begin{array}{c}\text { Monument } \\
\text { Registration } \\
\text { Number }\end{array} \\
75 \\
\end{array}$} & \multirow{3}{*}{ Period } & \multirow{3}{*}{$\begin{array}{l}\text { Type } \\
\text { Commercial }\end{array}$} & \multirow{3}{*}{$\begin{array}{l}\text { Usage } \\
\text { Wikala }\end{array}$} & \multirow{3}{*}{$\begin{array}{c}\text { Condition } \\
\text { Partially } \\
\text { col- } \\
\text { lapsed }\end{array}$} & \multirow{3}{*}{$\begin{array}{c}\text { Structure Material } \\
\begin{array}{c}\text { Limestone, lime-based } \\
\text { mortar, rubble infill }\end{array}\end{array}$} & \multicolumn{5}{|c|}{ Characteristics of Multiple Leaf Masonry Walls } & \multirow{3}{*}{$\begin{array}{c}\begin{array}{c}\text { Slenderness } \\
\text { Ration }(\lambda)\end{array} \\
2.5-6.5\end{array}$} & \multirow{2}{*}{\multicolumn{2}{|c|}{$\begin{array}{l}\text { Core Ratio \% } \\
\text { int./W. }\end{array}$}} \\
\hline & & & & & & & \multirow{2}{*}{$\begin{array}{c}\begin{array}{l}\text { Wall T } \\
\text { From }\end{array} \\
0.7\end{array}$} & \multirow{2}{*}{$\begin{array}{c}\text { kness } \\
\text { to }\end{array}$} & \multirow{2}{*}{$\begin{array}{c}\begin{array}{c}\text { Width o } \\
\text { ext. }\end{array} \\
0.20-0.25\end{array}$} & \multirow{2}{*}{$\begin{array}{c}\text { eaves } \\
\text { int. } \\
0.3-1.2\end{array}$} & \multirow{2}{*}{$\begin{array}{c}\begin{array}{c}\text { Leaves Ratio } \\
\text { int./ext. }\end{array} \\
1.5-5\end{array}$} & & & \\
\hline & & & & & & & & & & & & & 42.9 & 70.6 \\
\hline $\begin{array}{l}\text { Complex of } \\
\text { Sultan } \\
\text { al-Ashraf } \\
\text { Barsbay }\end{array}$ & 121 & & $\begin{array}{l}\text { Religious, } \\
\text { Educa- } \\
\text { tional, } \\
\text { Funer- } \\
\text { ary }\end{array}$ & $\begin{array}{l}\text { Khanqah, } \\
\text { Madrasa, } \\
\text { Mausoleum }\end{array}$ & Ruins & $\begin{array}{l}\text { Limestone, lime-based } \\
\text { mortar, rubble infill }\end{array}$ & 0.6 & 1.8 & $0.20-0.30$ & $0.2-1.4$ & $1-7$ & $6.0-8.0$ & 33.3 & 77.8 \\
\hline $\begin{array}{l}\text { Complex of } \\
\text { Sultan } \\
\text { al-Ashraf } \\
\text { Barsbay }\end{array}$ & 175 & & $\begin{array}{l}\text { Religious, } \\
\text { Educa- } \\
\text { tional, } \\
\text { Funer- } \\
\text { ary, } \\
\text { Water- } \\
\text { works }\end{array}$ & $\begin{array}{l}\text { Masjid, } \\
\text { Madrasa, } \\
\text { Mausoleum, } \\
\text { Sabil }\end{array}$ & Fair & $\begin{array}{l}\text { Limestone, lime-based } \\
\text { mortar, rubble infill }\end{array}$ & 0.9 & 3.9 & $0.20-0.25$ & $0.5-3.4$ & $2-13.5$ & 3.5-13.0 & 55.6 & 87.2 \\
\hline $\begin{array}{l}\text { Complex of } \\
\text { Sultan } \\
\text { al-Ashraf Inal }\end{array}$ & 158 & & $\begin{array}{l}\text { Religious, } \\
\text { Educa- } \\
\text { tional, } \\
\text { Funer- } \\
\text { ary }\end{array}$ & $\begin{array}{l}\text { Masjid, } \\
\text { Madrasa, } \\
\text { Mausoleum }\end{array}$ & $\begin{array}{l}\text { Partially } \\
\text { col- } \\
\text { lapsed }\end{array}$ & $\begin{array}{l}\text { Limestone, lime-based } \\
\text { mortar, rubble infill }\end{array}$ & 0.4 & 1.6 & $0.20-0.25$ & $0.08-1.2$ & $0.5-6.0$ & $6.0-10.0$ & 25.0 & 75.0 \\
\hline Bab Qaytbay & 278 & & Military & Gate & $\begin{array}{l}\text { Partially } \\
\text { col- } \\
\text { lapsed }\end{array}$ & $\begin{array}{l}\text { Limestone, lime-based } \\
\text { mortar, rubble infill }\end{array}$ & 0.7 & 6.75 & $0.20-0.30$ & $0.3-6.25$ & $12.5-25$ & $1.0-4.0$ & 42.9 & 92.6 \\
\hline $\begin{array}{l}\text { Masjid } \\
\text { Bardbak } \\
\text { (Umm } \\
\text { al-Ghulam) }\end{array}$ & 25 & & Religious & Masjid & Fair & $\begin{array}{l}\text { Limestone, lime-based } \\
\text { mortar, rubble infill }\end{array}$ & 0.6 & 1.1 & $0.20-0.25$ & $0.2-0.7$ & $1-3.5$ & 8.0-10.0 & 33.3 & 63.6 \\
\hline $\begin{array}{l}\text { Complex of } \\
\text { Sultan } \\
\text { Qansuh } \\
\text { al-Ghuri }\end{array}$ & $65-67$ & & $\begin{array}{l}\text { Religious, } \\
\text { Educa- } \\
\text { tional, } \\
\text { Funer- } \\
\text { ary }\end{array}$ & $\begin{array}{l}\text { Masjid, } \\
\text { Madrasa, } \\
\text { Mausoleum }\end{array}$ & V. good & $\begin{array}{l}\text { Limestone, bricks, } \\
\text { lime-based mortar, rubble } \\
\text { infill }\end{array}$ & 0.8 & 2 & $0.20-0.25$ & $0.4-1.4$ & $2-4.5$ & 8.0-17.5 & 50.0 & 70.0 \\
\hline
\end{tabular}


Table 1. Cont.

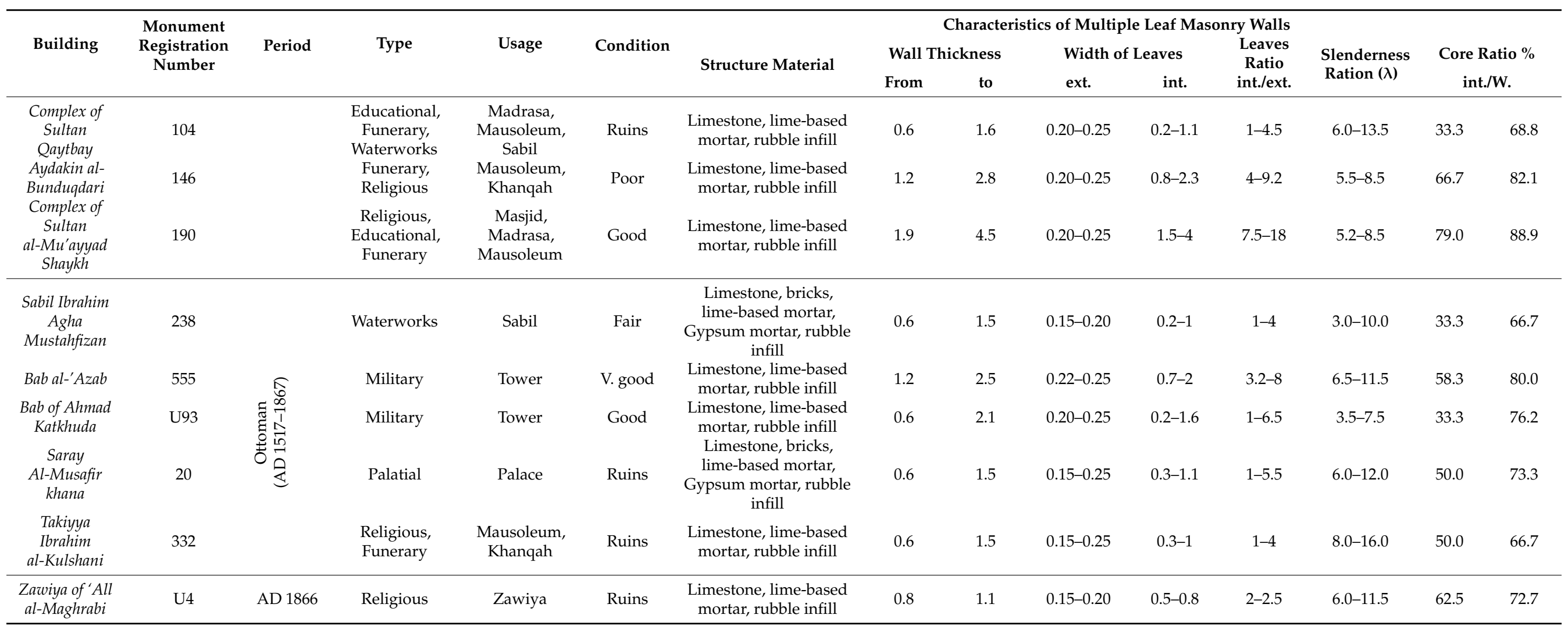




\section{Field Survey}

\subsection{Adopted Methodology}

An intensive survey was carried out for each building. The fieldwork focused on construction technology, building materials, and dimensions of multiple-leaf stone masonry walls. The survey included the overall thickness of the walls and their construction materials and the relative thickness of each layer, the overall slenderness ratio of the walls, block dimensions, the composition of the inner core layer, and the connectivity between the walls' leaves.

In the meantime, the constituent materials (stones, bricks, mortars) of the selected buildings were characterized and laboratory tested. The survey included various typologies and usages of historic masonry buildings in order to correctly investigate the construction criteria of multi-leaf stone masonry walls and covered different historical periods from the Fatimid to the Ottoman era.

The methodology adopted for the fieldwork allowed characterizing the transversal section of the multiple-leaf masonry walls and also yielded definitions of some critical parameters regarding the structural typology of the multiple-leaf masonry walls, i.e.,:

(i) The relative thicknesses of the different layers;

(ii) The ratio between the thicknesses of the inner layers and the total cross-section of the wall;

(iii) The filling materials used to construct the inner core layer;

(iv) The connectivity/constraints types between the inner and external layers;

(v) The construction techniques of the multiple-leaf masonry wall.

Furthermore, three hypotheses were established concerning the utilized construction techniques through extensive field and laboratory investigations.

The adopted geometrical survey followed the methodology provided by Binda et al. [43], where visual inspection and graphic and photographic procedures were conducted to reproduce the metric survey of the studied walls by approximating the geometry with analytical expressions to calculate the percentages of voids, stone units, and mortar joints. Various stone, mortar, and core infill samples were collected and laboratory investigated, and the results were reported in detail in $[7,44]$. Since the behavior of masonry walls is highly dependent on the technique of construction, the obtained geometrical parameters - together with the characterization of chemical, physical, thermal, petrographic, and mechanical properties $[7,25,44]$ of the materials—give the possibility of better describing multiple-leaf masonry walls and constitute a fundamental basis for the mathematical modelling and the appropriate choice of conservation and retrofitting techniques.

\subsection{Major Findings}

\subsubsection{Usage}

To a large extent, the multiple-leaf stone masonry walls were used primarily in the lower floor levels and could extend to the entire wall height of external façades or some major interior walls of the building. In addition, most of the thick stone masonry walls were built according to the multi-leaf system with two outer leaves of more robust material and an inner one of weaker materials; this allowed for a thicker wall cross-section and consequently higher own weight (which increases the overall stability of the wall) at a comparative economic cost.

\subsubsection{Geometry}

The majority of the multi-leaf walls have an overall thickness greater than $0.5 \mathrm{~m}$, ranging from slender to monolithic walls with a variable relative thickness of inner and external layers. Figure 3 provides typical cross-sections of multiple-leaf stone masonry walls of different thicknesses. Mostly, the external layers were built with a homogeneous distribution of the regular well-dressed stone blocks, with nearly constant or uniform dimensions (ashlar facing system). Less homogeneously distributed stone rubble units randomly cut from quarries were often used as infill between the outer leaves. In some 
cases, a transversal connection between the inner and external skins was provided by irregularly disposed and through passing elements. These transversal bond elements were used to enhance the connectivity between the wall's leaves.
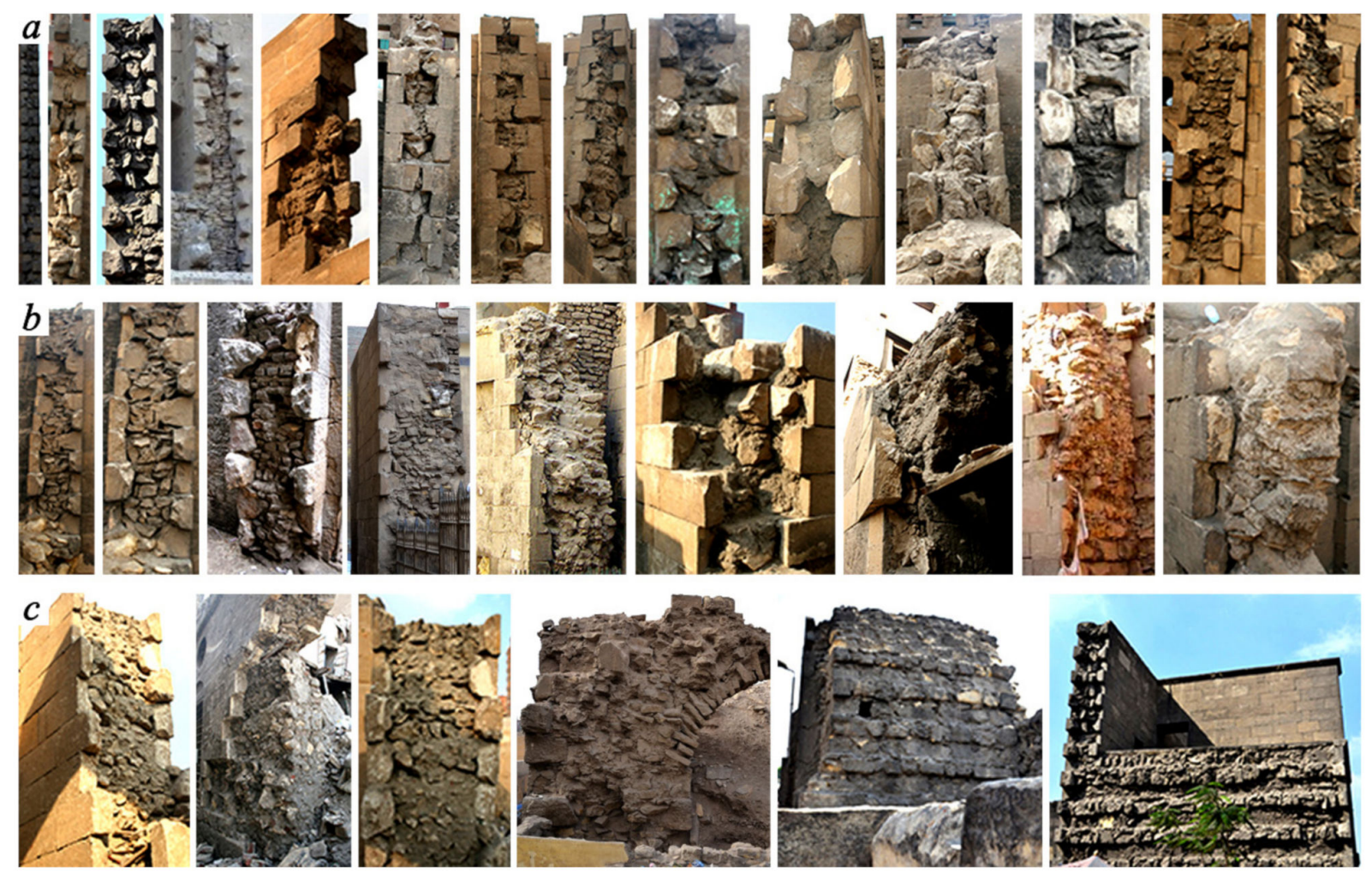

Figure 3. Typical cross-sections of different thicknesses of multiple-leaf stone masonry walls: (a) slender wall [ $\left.\frac{\text { Int. }}{E x t} \leq 0.35\right]$, (b) wall of medium thickness [0.35 $\left.<\frac{\text { Int. }}{\text { Ext. }}<1.5\right]$, (c) thick (monolithic/massive) wall [ $[$ Int. $\geq 1.5]$.

According to the collected data and field survey results, the thickness of the three-leaf stone masonry walls ranged from 0.5 to more than $6 \mathrm{~m}$ (Figure 4). It should be stressed that walls with thickness lower than $0.5 \mathrm{~m}$ were rare (about $0.94 \%$ of the total surveyed walls), while the percentage of the walls with a thickness of more than $4 \mathrm{~m}$ was about $6.6 \%$ of the total surveyed walls. Subsequently, the field survey results confirmed that the majority of the multi-leaf stone masonry walls had a thickness range from 0.5 to $4.0 \mathrm{~m}$.

It is worth mentioning that the walls that were more than $4.0 \mathrm{~m}$ thick, and may have reached more than $6 \mathrm{~m}$, were commonly used in the high-rise main facades (as in the Complex of Al-Sultan Hasan) and were often used in military defense buildings (as in Bab Qaytbay).

This high value of the walls' thickness could be attributed to the need to increase the wall's strength and stiffness in order to enhance the overall mechanical stability and safely resist lateral loads and any expected impact loads. On the other hand, buildings with residential or religious utilization were commonly built with a wall thickness of fewer than $4 \mathrm{~m}$. Thus, it can be inferred that the thickness of the multi-leaf masonry walls was mainly dependent on the function of the building and the overall height of the wall. 

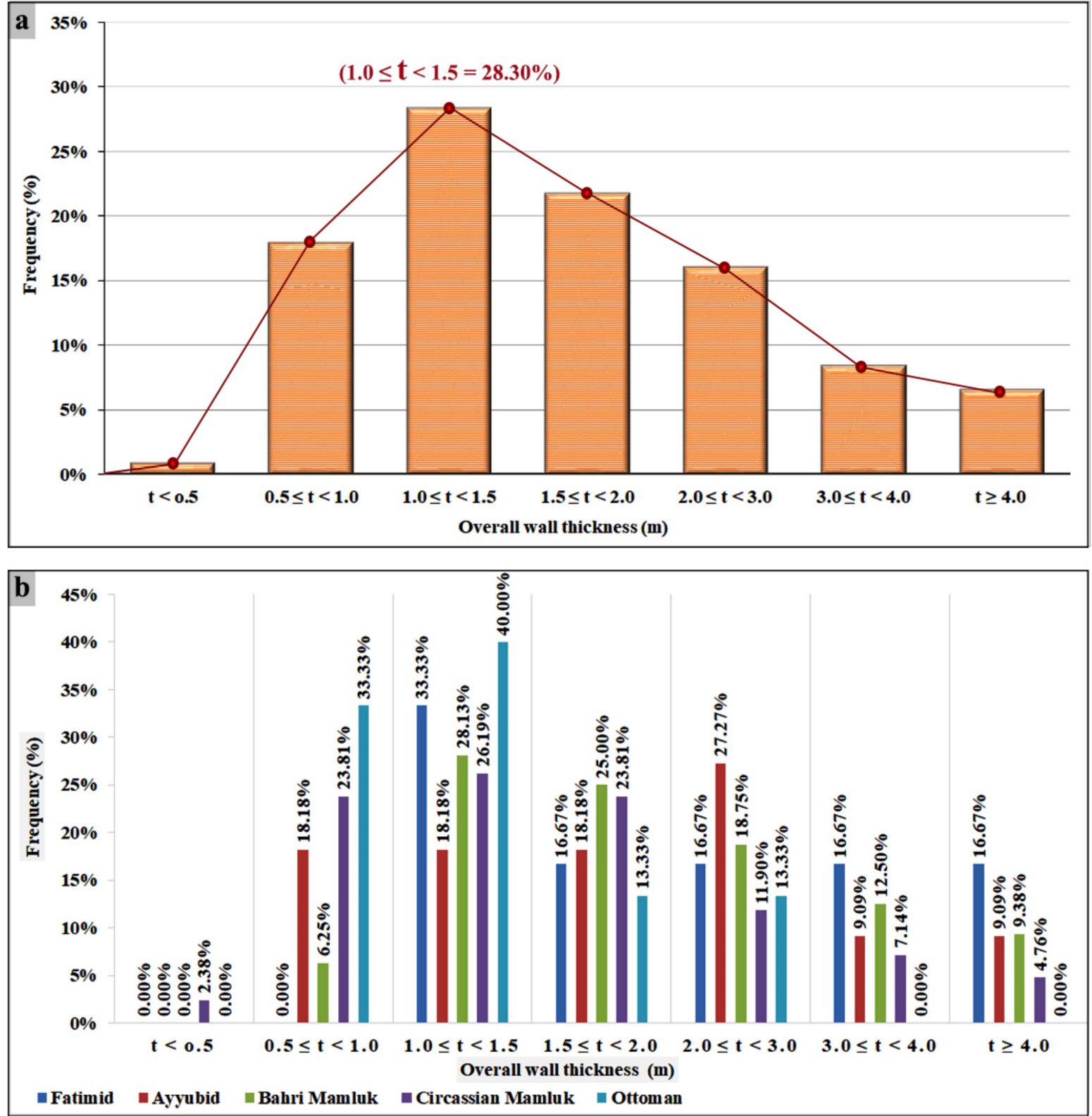

Figure 4. Analyses of the field survey results regarding the thickness of the multiple-leaf masonry walls: (a) all surveyed buildings; (b) surveyed buildings according to their historic period; Fatimid, Ayyubid, Bahri Mamluk, Circassian mamluk and Ottoman periods, respectively.

\subsubsection{Typology}

Three main typologies could be characterized from the analysis of collected data and field survey results as follows: 
1. Walls with straight collar joints, where the inner layer was not interconnected with the outer layer. Usually, the inner layer was constructed with an utterly cohesionless infill held by two separate external leaves, while the outer leaves were made of welldressed limestone blocks with nearly uniform dimensions, ashlars limestone facing system, bonded in horizontal courses. Only a thin interface layer of mortar was found between the three layers (see Figure 5).

2. Walls with keyed collar joints, where the external layer was built with ashlars limestone blocks with variable thickness, creating shear studs to ensure proper connectivity with the inner core infill (see Figure 6a-d).

3. Walls with the transversal bond or tie elements in the cross-linking of the three layers by the use of either header stones (through stones), timber logs or circular marble elements; this ultimately ensured the composite behavior of the wall and enhanced the global performance with the applied external loads (see Figure 6e,f).
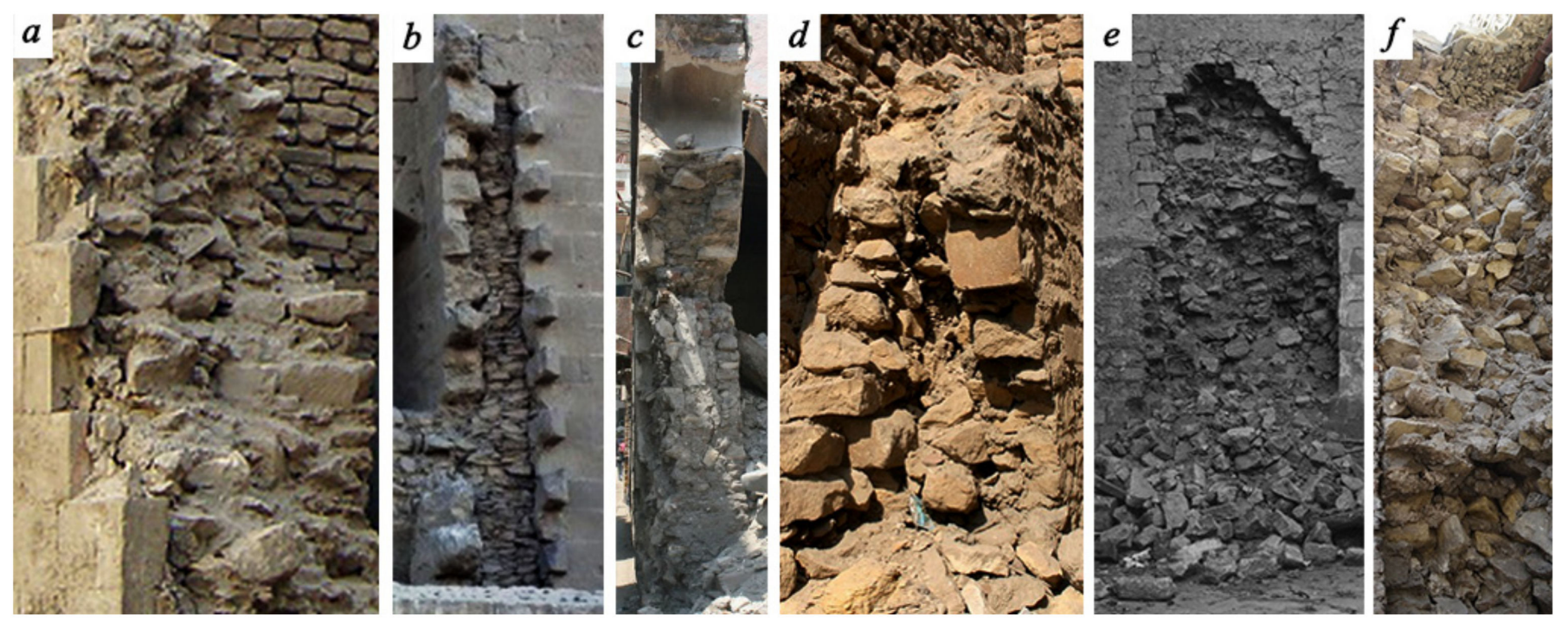

Figure 5. Examples of multi-leaf walls with straight collar joints and a cohesionless inner core layer built of rubble stone masonry: (a) Khanqah of Aydakin, (b) Complex of Al-Sultan Hasan, (c) Zawiya of 'All al-Maghrabi, (d) Khanqat Khawand Umm Anuk, (e) Complex of Al-Sultan Qalawun, and (f) Wakala al-Sultan Qaytbay. 

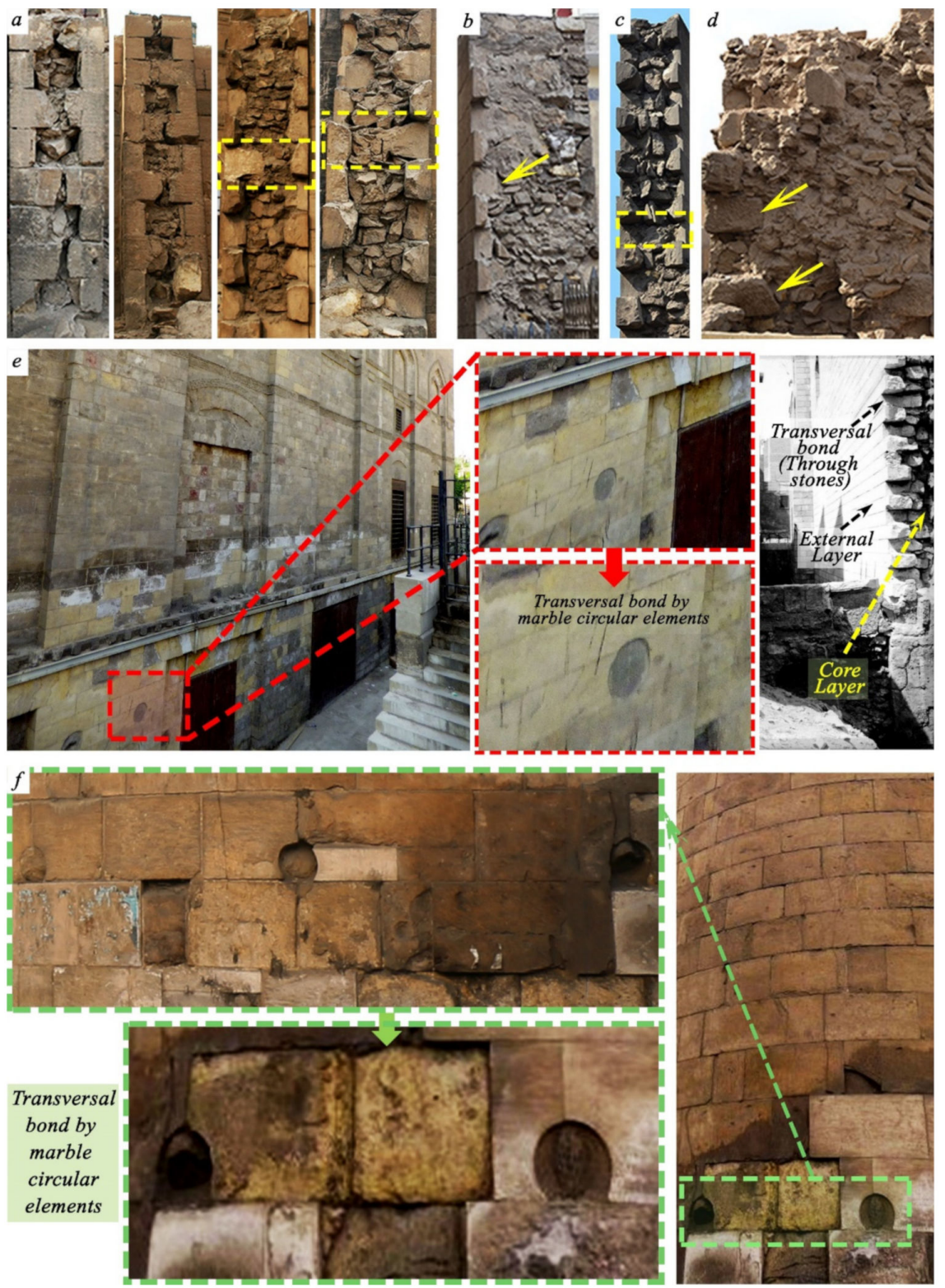

Figure 6. Transversal bond elements between the inner and external leaves of the wall: (a-d) crossheader stones/shear keys (Complex of Sultan al-Ashraf Barsbay, Amir Alin Aq Palace, Bab Qaytbay, and Qasr al-Amir Qawsun, respectively); (e,f) marble circular cross-joists, (Masjid al-Salih Tala'i' and Bab Zuwayla, respectively). Adapted from [7].

\subsubsection{Constituent Materials}

According to the conducted metric survey regarding the composition of multi-leaf stone masonry walls, stone constituted at least $60 \%$ of the section, while mortar constituted $25 \%$ to $37 \%$. Limestone was the most used stone unit in both external and inner layers. The maximum dimension of rubble stones in the core layer varied from 10 to about $40 \mathrm{~cm}$, with an average of $20 \mathrm{~cm}$, while the average stone block in the outer leaves measured $25 \times 35$ $\times 50 \mathrm{~cm}$. Most of the mortars were made of air-hardening lime, usually with a powdery and brittle consistency $[7,25]$, and the dimensions of mortar joints were irregular and, on average, varied between 1 and $5 \mathrm{~cm}$. Mostly, the core layer of the majority of the survey walls was built mainly of stone-rubble infill. Nevertheless, in some buildings dating back to the Ottoman period-for example Sabil Ibrahim Agha Mustahfizan and Saray Al-Musafir khana (see Figure 7) - the core layer was built of brick rubble. 

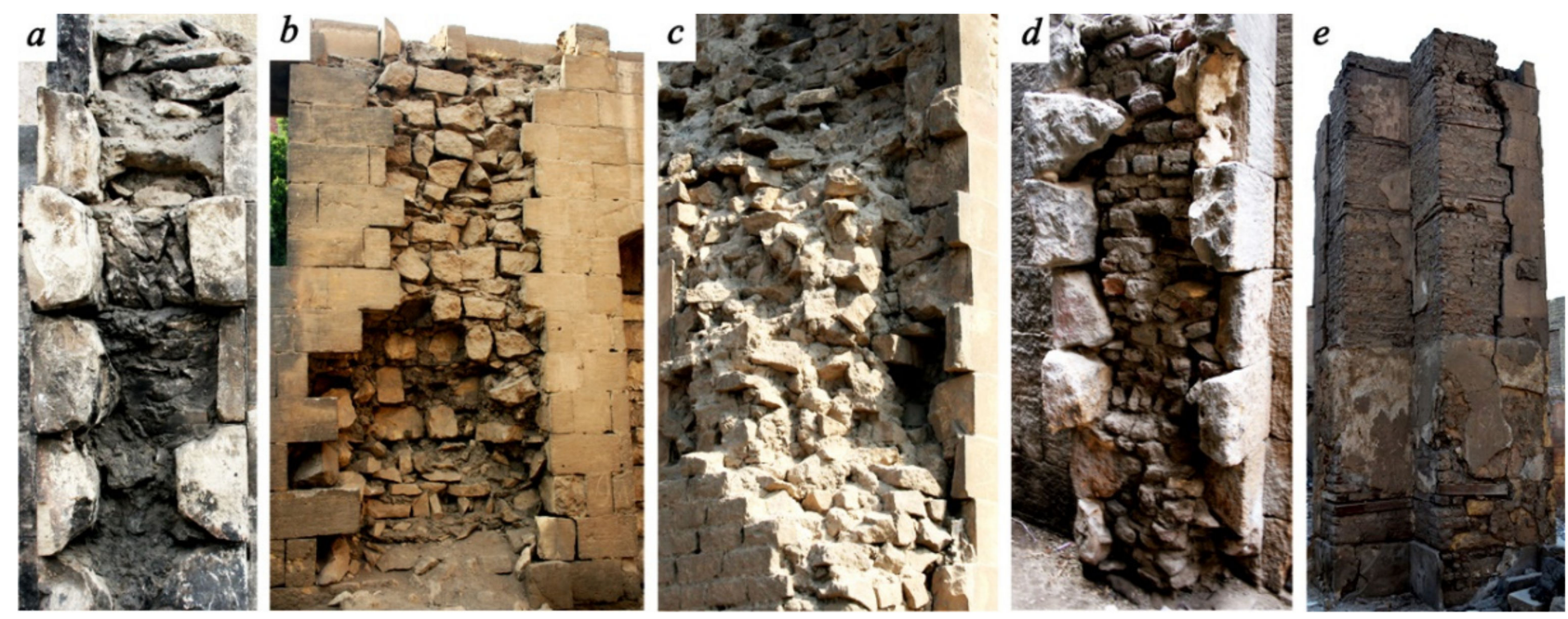

Figure 7. Different core infill materials of multiple-leaf masonry walls: (a-c) stone-rubble infill—Complex of Sultan al-Ashraf Barsbay, (d,e) brick rubble infill, (a,b) Complex of Sultan al-Ashraf Barsbay, (c) Khanqat Khawand Umm Anuk, (d) Sabil Ibrahim Agha Mustahfizan, (e) Saray Al-Musafir khana Zawiya of 'All al-Maghrabi.

\subsubsection{Characterization of the Inner and External Layers}

The thickness of both external layers was mostly similar and usually less than the inner layer. Also, the percentage of their thickness in relation to the overall thickness of the wall was nearly constant. Furthermore, these external layers were mainly built of well-dressed stone blocks with nearly uniform dimensions (ashlars limestone facing system). The dimensions of the stone-rubble infill varied according to the total thickness of the inner layer. In the case of a thick to monolithic core layer, the thicknesses of mortar joints were usually much lower than the thickness of stone rubble, and the percentage of voids was relatively low; consequently, the presence of rubble stones settled in a high percentage ensured a dense and well compacted core infill.

The thickness of the core layer of the majority of the surveyed walls ranged from 0.5 to $2 \mathrm{~m}$, and the percentage of the core layer with thickness lower than $0.5 \mathrm{~m}$ was about $14.5 \%$ (see Figure 8 ). 

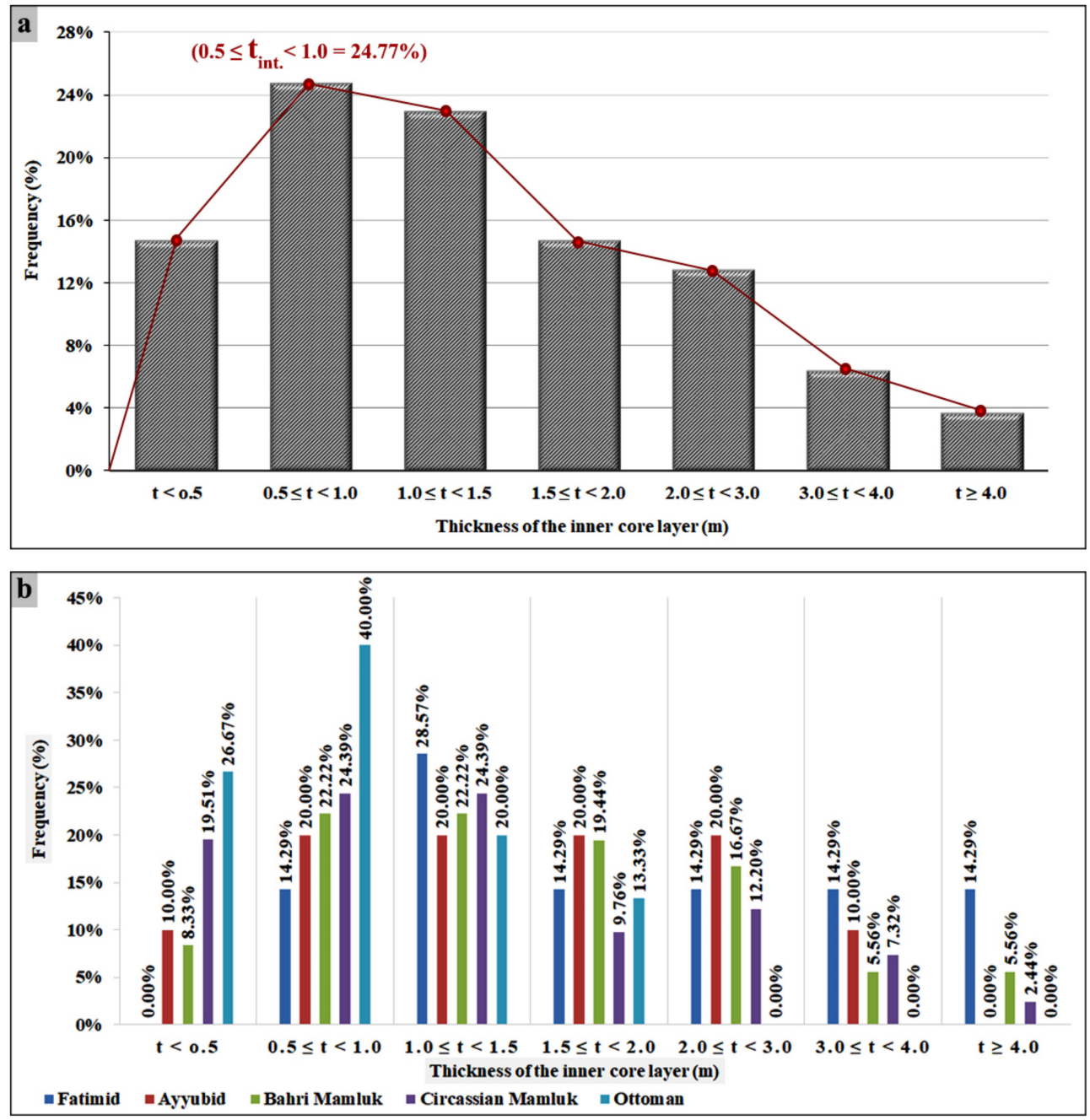

Figure 8. Analyses of the field survey results regarding the thickness of the inner core layer of the multiple-leaf masonry walls: (a) all surveyed buildings; (b) surveyed buildings according to their historic period: Fatimid, Ayyubid, Bahri Mamluk, Circassian mamluk, and Ottoman periods, respectively.

\subsubsection{Relative Thickness of the Layers}

Based on the analysis of fieldwork results, it can be stated that the ratio between the thicknesses of inner and outer layers depended entirely on the required thickness of the wall. Since the thickness of both external layers was similar and also their percentage to the overall thickness of the wall was about constant, the ratio between the core layer's thickness and the overall thickness of the wall varied according to the total thickness of the cross-section, see Figure 9. Moreover, the ratio between the thicknesses of inner and exterior layers (int./ext.) in most of the walls ranged from 1 to 10 , where this percentage increased as the total thickness of the wall increased.

In the case of the cohesive core infill layers that were characterized by good mechanical properties and relatively high stiffness, the thickness of the core layer was considerably larger than the thickness of the outer layer. This could be observed-for example-in high-rise and military defense constructions, where the total wall thickness exceeded $4 \mathrm{~m}$. In this case, a much higher proportion of the applied loads was countered by the inner layer. Since the applied vertical compressive load on the wall is distributed according to the ratio between modulus of elasticity and thickness of the wall, assuming uniform vertical strain (as shown by Egermann et al. [45] and Binda et al. [8,46]), a simplified modeling of the distributed vertical loads, $P_{e}$ and $P_{i}$, acting on the outer and inner leaves, respectively, could be obtained from Equation (1). 

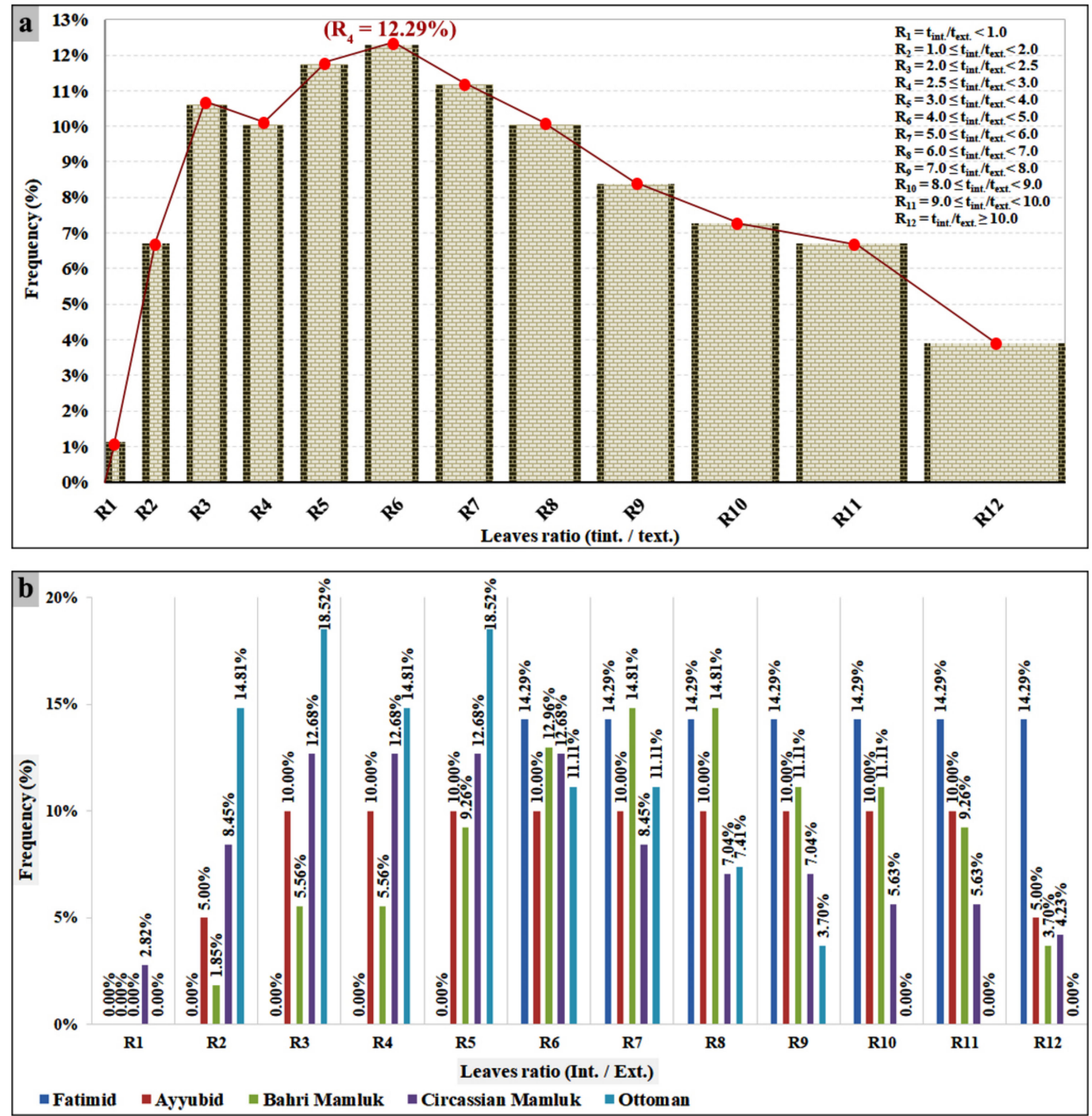

Figure 9. Analyses of the field survey results regarding the ratio between the internal and external leaves thicknesses of multiple-leaf masonry walls: (a) all surveyed buildings; (b) surveyed buildings according to their historic period: Fatimid, Ayyubid, Bahri Mamluk, Circassian mamluk and Ottoman periods, respectively.

$$
P_{i}=\left(\frac{1}{1+2 \frac{E_{e} t_{e}}{E_{i} t_{i}}}\right) p \quad P_{e}=\left(\frac{1}{2+\frac{E_{i} t_{i}}{E_{e} t_{e}}}\right) p
$$

where $p$ is the initial total applied load; $E_{e}$ and $E_{i}$ are the moduli of elasticity of the outer and inner leaves respectively; $t_{e}$ and $t_{i}$ are the thicknesses of outer and inner leaves, respectively. Further details of the load transfer mechanism will be provided in a forthcoming paper.

Under the same characteristics of the wall, loading, and boundary conditions, the increase in the thickness of core layer and, consequently, the increase in the overall thickness of the wall, significantly reduced the resultant internal compressive and shear stresses.

Furthermore, the thickness of the walls often increased as the total height increased, keeping the slenderness ratio between 3 to 12 (Figure 10). However, a relatively small number of the surveyed walls had a ratio larger than 12 .

Finally, the obtained results of the fieldwork alongside the analysis of the typical cross-sections of the three-leaf masonry walls and the survey of different typologies have contributed to form a thorough scientific base for the construction hypothesis of this distinctive type of historic wall, which will form a fundamental reference for any further experimental studies on their structural behavior. 

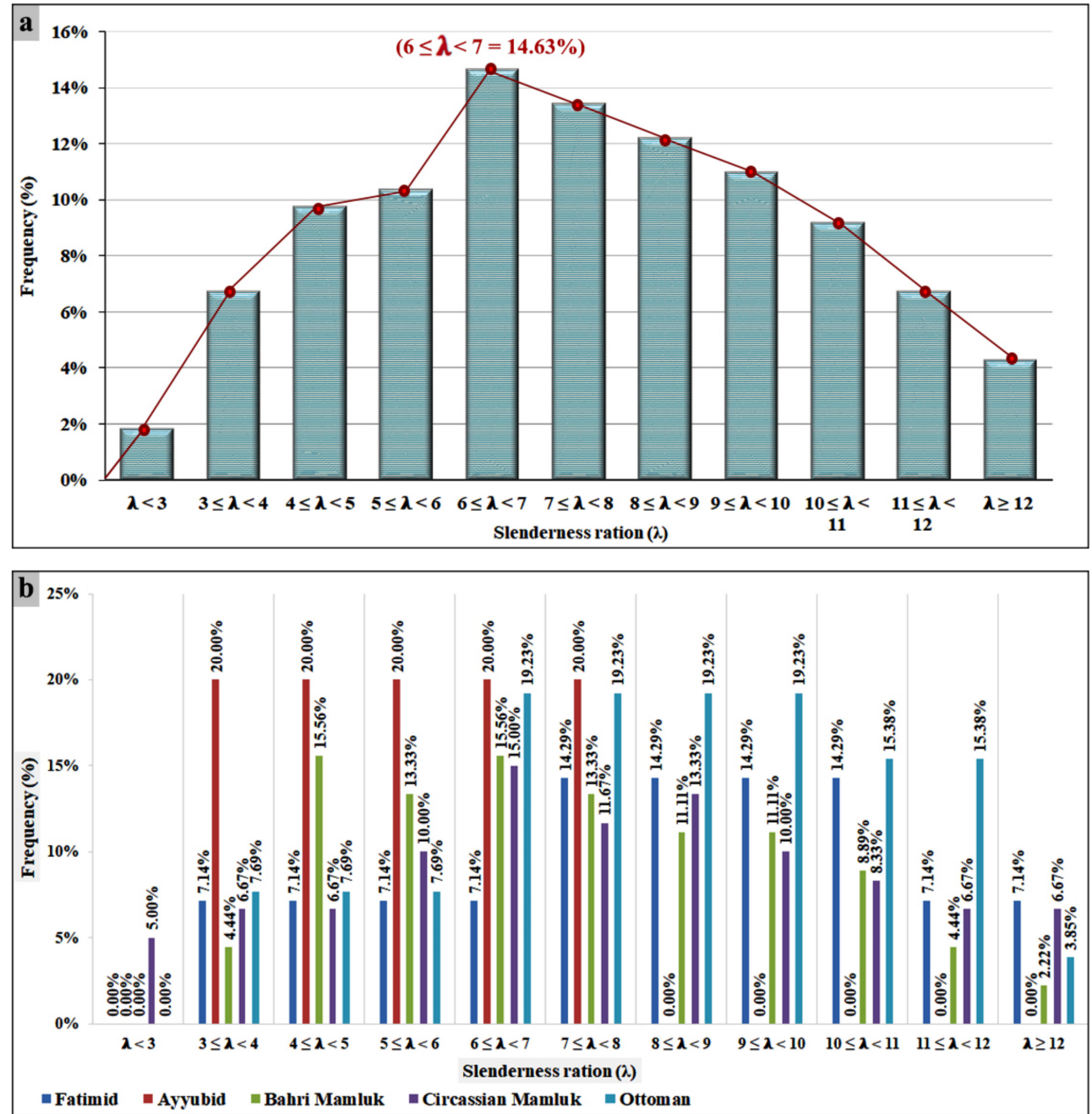

Figure 10. Analyses of the field survey results regarding the slenderness ratio of the multiple-leaf masonry walls: (a) all surveyed buildings; (b) surveyed buildings according to their historic period: Fatimid, Ayyubid, Bahri Mamluk, Circassian mamluk and Ottoman periods, respectively.

\section{Construction Hypotheses of Multiple-Leaf Masonry Walls}

This section focuses on the construction hypotheses of multi-leaf stone masonry walls in accordance with the field survey results. Although multi-leaf stone masonry walls are one of the common building systems and have been widely used in a variety of historical constructions, there is a considerable lack of information about the utilized methods and techniques for their construction. This type of wall can be characterized by different construction techniques, which essentially affect their mechanical behavior, in particular the interaction between the layers and the overall integrity of the wall.

Three hypotheses could be made on the construction techniques based on the typology, overall thickness of the wall, and the connectivity between the inner and outer layers, as described in the following subsections.

\subsection{Construction Hypothesis (I): Weak Inner Core}

A first hypothesis assumes that the multi-leaf masonry walls were built with almost a thoroughly segregated/cohesionless internal core retained by two separate external leaves (Figure 5). The walls were mainly constructed by building the outer two layers first, leaving a space or cavity of the designed thickness for the core infill between the outer leaves by laying a course of stretcher stone blocks along the chalk line for the entire length of the wall after determining the opening positions (Figure 11a). Then, in correspondence with the 
corners and openings, adjacent courses of stone blocks were carefully laid. These provided a guide for laying the remaining blocks, so they should be accurately leveled and correctly spaced. String lines were then stretched between corners of the wall or between a corner and an opening's edges (Figure 11b). To ensure that the wall would be straight and not bowed or curved, the first course of the lead was carefully aligned and was usually at least four or five units long. Leads were usually built four to five courses higher than the central part of the wall, and each course of the lead was carefully checked to accurately assure that it was leveled in both directions and plumb.

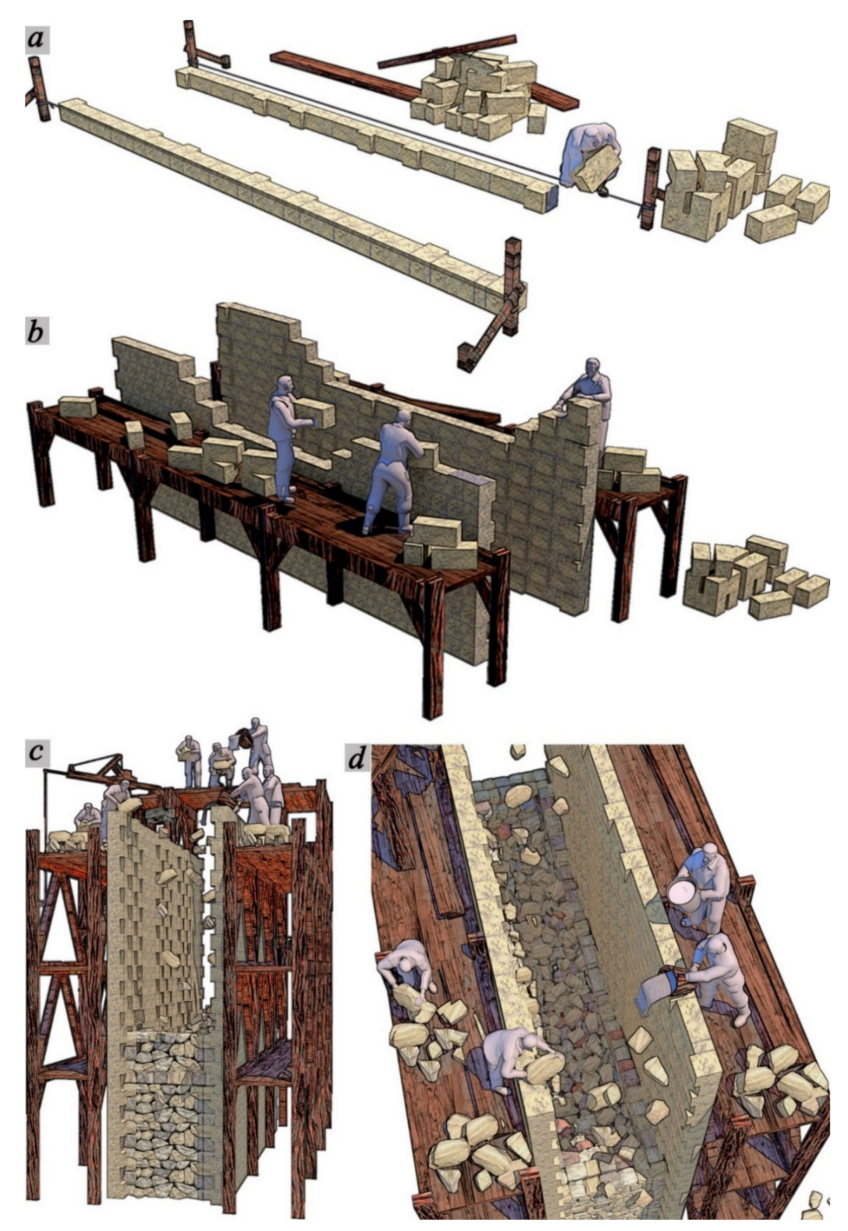

Figure 11. Construction hypothesis (I): (a) laying the first course of stretcher stone blocks along the entire length of the wall; (b) construction of the two outer leaves; (c,d) pouring and throwing of the inner core leaf.

After that, the outer shells were brought up to the total height of the wall by laying the stone blocks up with mortar in specific patterns, providing a typical running bond in which one unit overlapped the unit in the course below by almost half its length. This bonding was aimed at homogenously spreading the loads and increasing the interconnectivity between the stone blocks. In most cases, timber logs were embedded horizontally along the length of the wall at considerable interval heights (about 1.0 to1.50 m), as shown in Figure 12 , in order to properly adjust the wall verticality, ensure that walls were going up plumb, and offer a good bedding level for successive wall courses. When the two outer layers had been brought up to the required height of the wall, the core infill was simply poured or thrown until the top of the wall was reached (Figure 11c,d). This infill was generally composed of rubble stones bonded with mortar. In some cases, the three layers may be bonded together using transversally bound elements of stone, wood, or marble. However, their use may have impeded the casting process of the inner layer. 

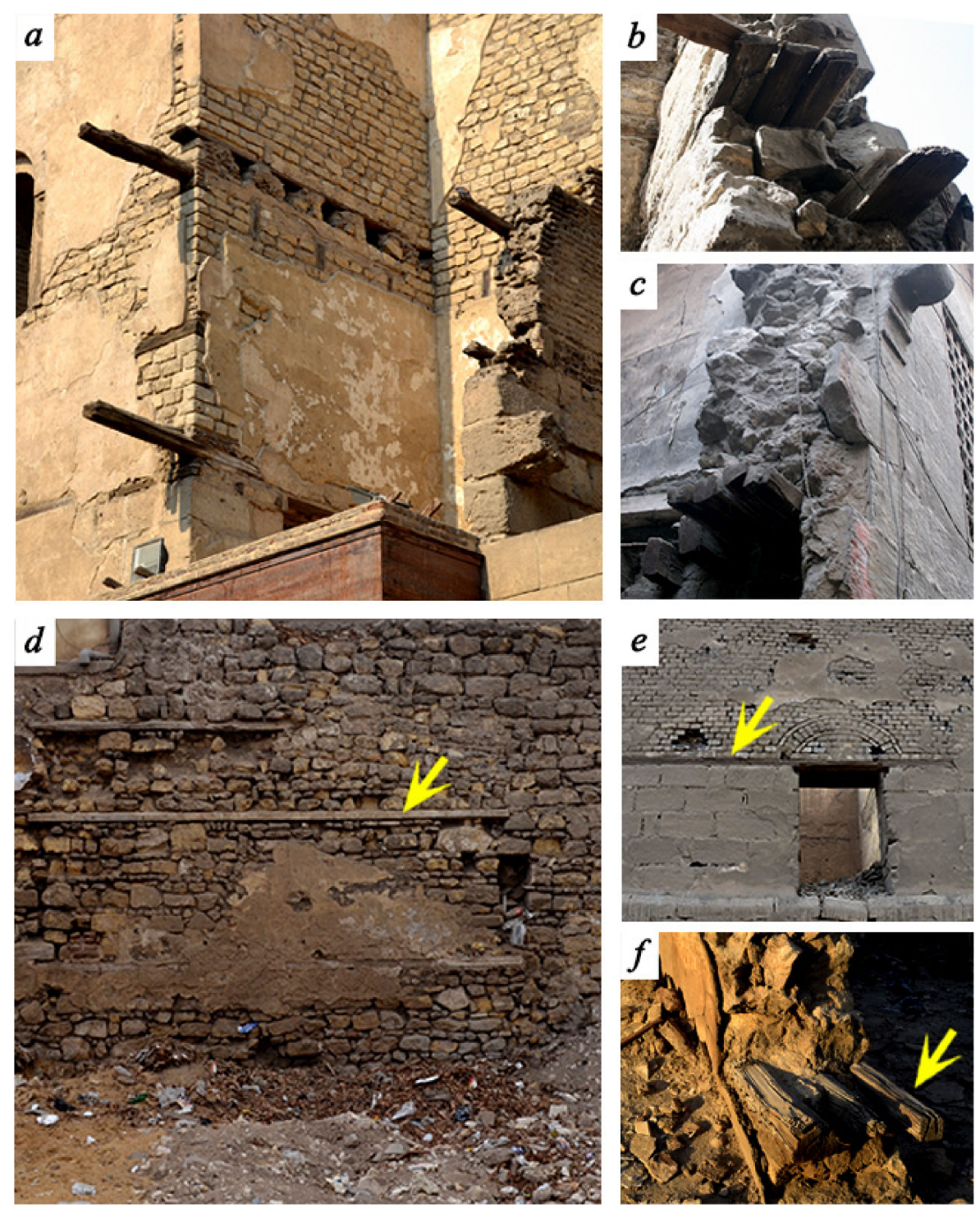

Figure 12. Timber tie system in stone masonry constructions: (a) Amir Alin Aq Palace, (b) Sabil Ibrahim Agha Mustahfizan, (c) Qasr al-Amir Qawsun, (d,e) Qasr al-Amir Qawsun, (f) Takiyya Ibrahim al-Kulshani.

It is believed that, during construction, the outer leaves were temporarily braced with the use of timber cross-braces frame (timber ledger) so that the pouring of the core infill was suitably set to prevent any lateral loads produced during the casting/filling process from exceeding their structural capabilities and to avoid detachment, buckling, or expulsion of the outer leaves.

The construction of multi-leaf walls by following this technique produces walls with a weak and incoherent core layer. As a result of casting the core infill after the complete construction of the outer layers, segregation may occur between the mortar and the rubble infill. Accordingly, it is believed that this method was of limited use for thin walls and walls of limited heights. Nevertheless, it is interesting to observe that this method has been exploited in more recent historic buildings, as in the construction of Gebel Aulia dam in Sudan, 1904; Mohamed Aly barrage in Egypt, 1941; and Aswan High Dam, 1970, where the well-dressed granite blocks were used as facing/shuttering layers, while granite rubble masonry was used for filling the cross-section (see Figure 13). Through the development of the construction materials and for structural upgrading purposes, the rubble masonry of the core layer was replaced with mass concrete and the timber logs were also replaced by reinforcing steel bars, as in the majority of the old irrigation structures in Egypt [47]. 

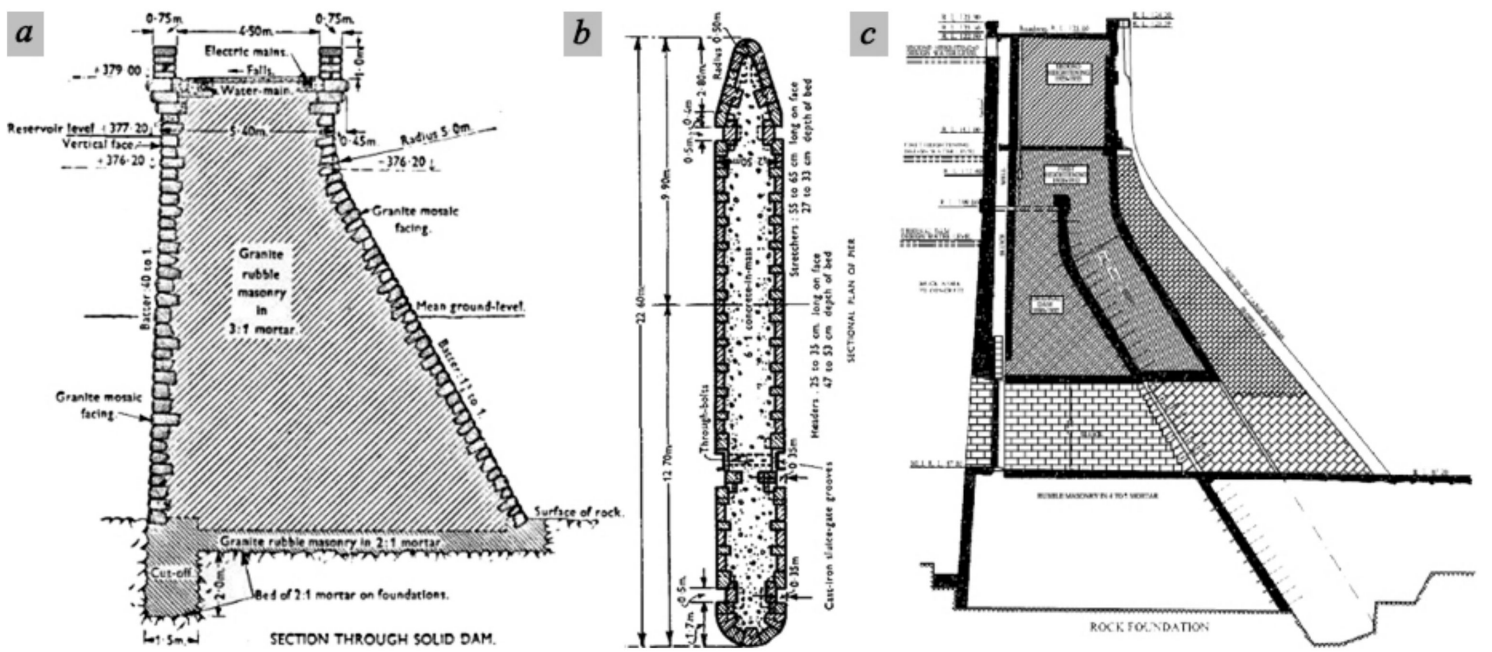

Figure 13. Archived cross-sectional drawings of (a) Gebel Aulia Dam, (b) Mohamed Aly Barrage, and (c) Aswan High Dam.

\subsection{Construction Hypothesis (II): Monolithic Core Infill}

The second hypothesis concerning the construction technique adopted for monolithic multi-leaf masonry walls assumes a thick core infill faced with relatively light sheeting of ashlar facing stone masonry to form the enclosed/composed element. According to this hypothesis, the inner core layer was firstly constructed in the intermediate space of the total cross-section of the wall by piling up undressed, rough stones, as they were randomly cut from quarries and sufficiently bonded with mortar without being committed to horizontal courses. In this case, the longitudinal bond in the core skin was achieved by overlapping stones in roughly adjacent courses, with a variable amount of overlap as the stones varied in size. Relatively large stone blocks were cut in a reasonably prismatic block shape and were used for corners and the jambs of openings to obtain increased strength and stability at these locations. One of the most important concerns regarding the construction of the inner core layer was keeping it straight and plumb; this could be established by building leading sections or leads at the ends or corners of walls and string lines were then stretched between corners. These leads provided a guide for laying the remaining infill mixture at the middle of the wall length, see Figure 14a-c. After that, the inner core layer was completed until the required height of the wall. Then, it was coated/faced with two outer layers of regular well-dressed stone blocks (ashlar stone masonry facing system) (see Figure 14d,e).

Even though the inner layer is characterized by high cohesion and a significant loadbearing capacity, with a low percentage of voids, it was weakly bonded with the outer layers by only a thin interface layer of lime-based mortar, affecting the homogenous performance of the wall. Consequently, the internal leaf resists a relatively large portion of the applied vertical loads, while a small portion is carried by the outer layers. Besides, the adhesion between the leaves would have been scarce or null, and the inner core layer would exert lateral load on both outer leaves, causing detachment and separation. To overcome these deficiencies, the cohesion between the three layers was usually achieved through drilling some holes/apertures at the inner layer, in correspondence with specifically designed positions to insert the transversal bond or tie elements in the cross-linking of the three layers by the use of either header stones (through stones), timber logs, or circular marble elements.

An example of a more recent historic construction that confirmed this construction hypothesis is the Sanayta lock and bridge-regulator construction in Egypt (Figure 15) in 1899: the inner core layer of the multi-leaf walls of the lock were built first of brick masonry with Homra mortar, and then faces were cladded with cement mortar. The main portion of the wall has a width diminishing from $3 \mathrm{~m}$ to $1.2 \mathrm{~m}$, by steps of $0.25 \mathrm{~m}$. At the upstream end, these walls are encased with ashlar masonry in $0.4 \mathrm{~m}$ courses [48]. 

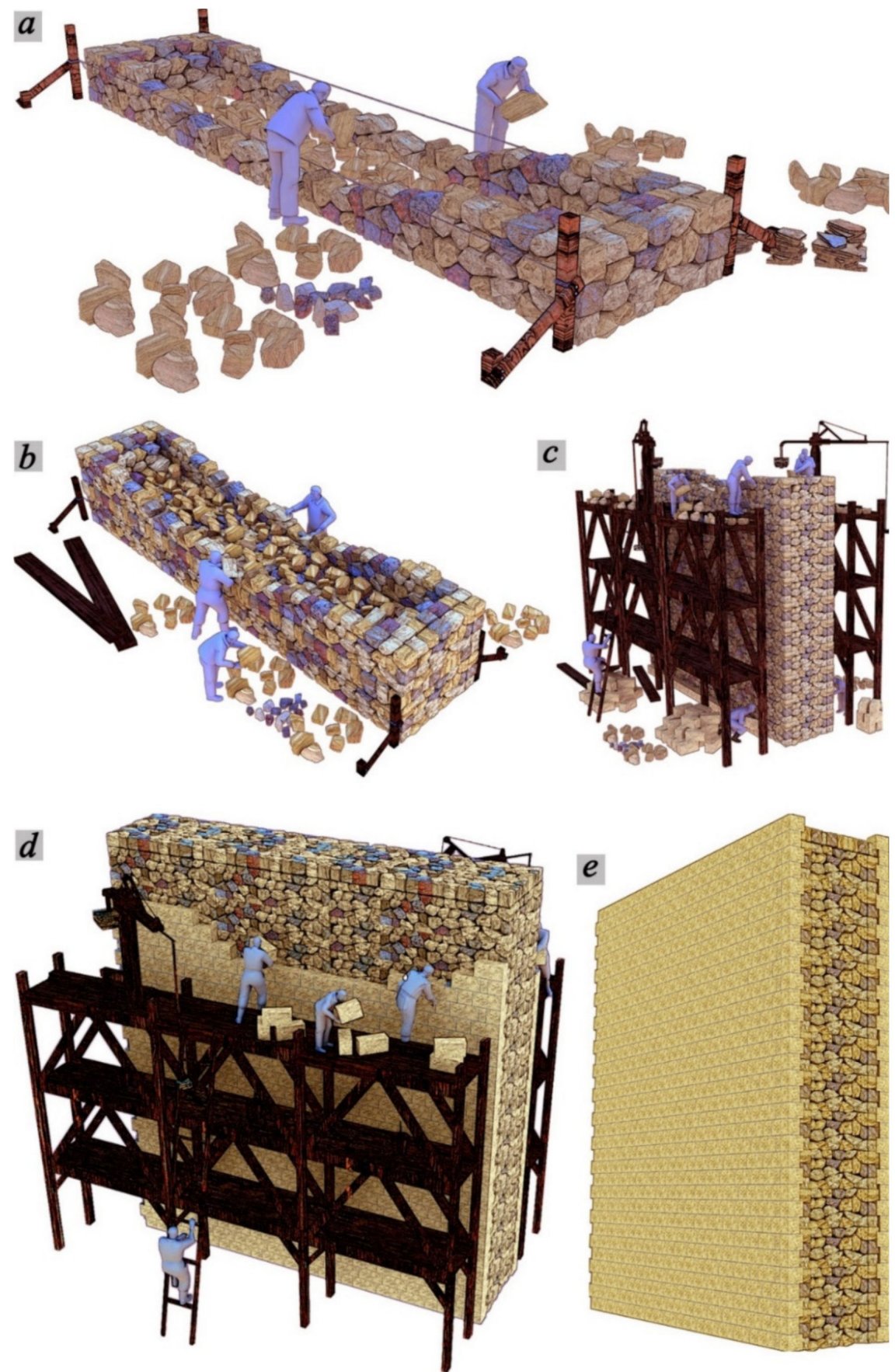

Figure 14. Construction hypothesis (II): (a-c) construction of the inner core layer by randomly piling up undressed, rough stone, which was bound with mortar without being committed to horizontal courses; (d) construction of the two outer leaves with regular well-dressed stone-blocks; (e) the full tree-leaf stone masonry wall. 


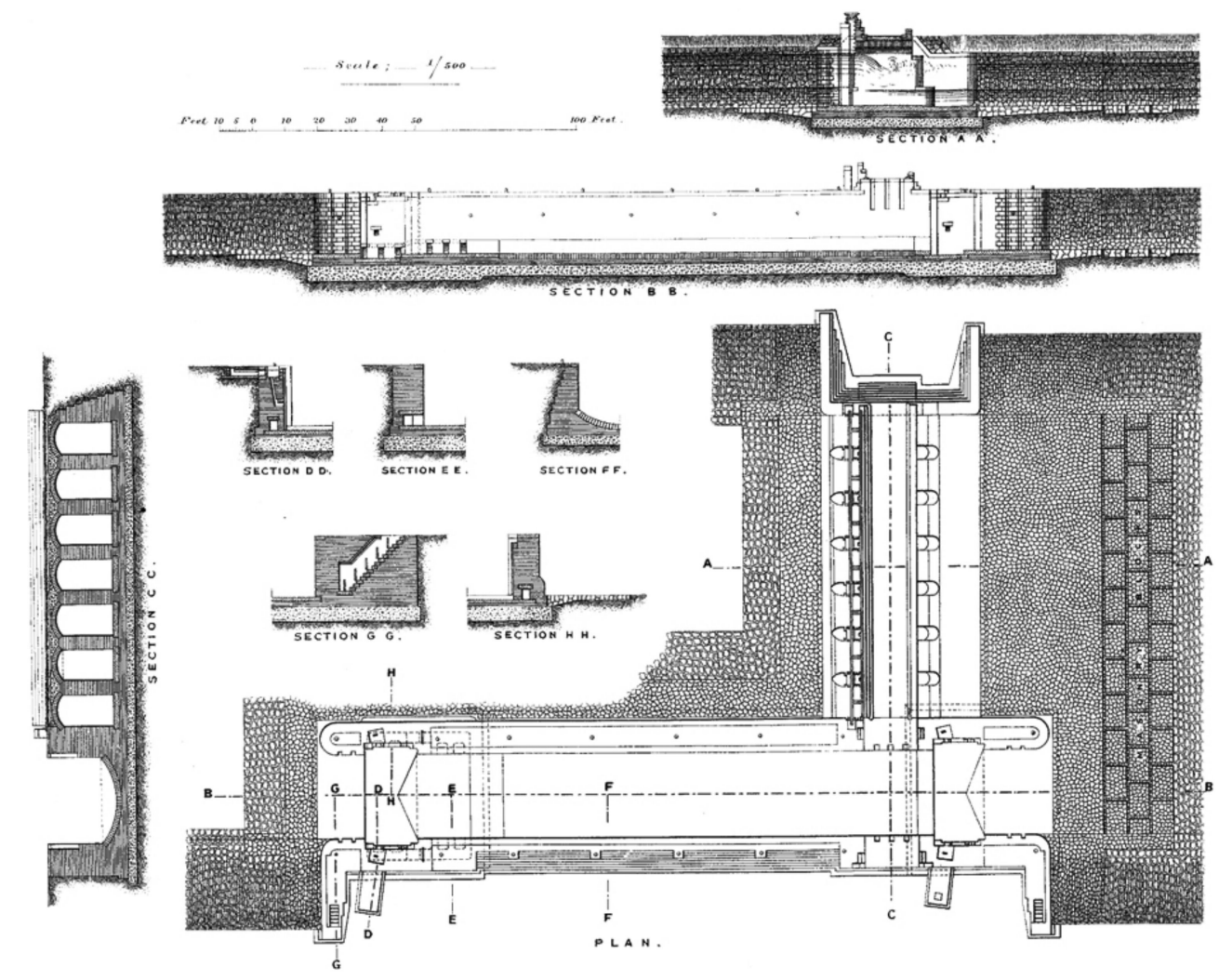

Figure 15. Archived drawings of Sanayta lock and bridge-regulator construction, adapted from [48].

\subsection{Construction Hypothesis (III): Thick Core Infill}

The third hypothesis on the construction technique adopted in three-leaf stone masonry walls is similar to the second one, since it is assumed that the inner core layer is characterized by high cohesion, good mechanical properties, and an actual load-bearing capacity with low percentages of voids. Furthermore, the presence of transversal bond elements (stone, timber, or marble joists) between the inner and external layers enhances the connectivity between the wall's leaves. The three layers are perfectly homogeneous in this type and behave as a single composite element to resist the applied loads, so that the lateral pressure of the inner core layer thrusting the outer leaves decreases significantly and almost vanishes. The vertically applied loads on the wall cross-section are distributed according to the relative stiffness of the core infill and the outer skins.

As regards this hypothesis, the three layers of the wall were simultaneously built. The two outer layers of the wall were constructed up to a suitable height (presumably three to four courses), and instantaneously the core infill was constructed in between. The two outer leaves were mainly built using well-dressed limestone blocks with nearly uniform dimensions (ashlar facing system), while the inner core layer was constructed mainly by successive layering of rubble stones and mortar bedding, which was not cast but layered more or less accurately by the masons (see Figure 16).

Providing a proper setting time for the infill mixture or mortar, the two outer layers were then continued up to an appropriate height and then the inner layer was also built up to the same height of the wall. Up to a certain height from the ground, the three layers could be constructed from both sides of the wall without any scaffolding (Figure 17a). Subsequently, it was essential to assemble the scaffolding for building the upper parts; the stone blocks were then lifted to the scaffolding platform by a hoist (Figure 17b-d). 

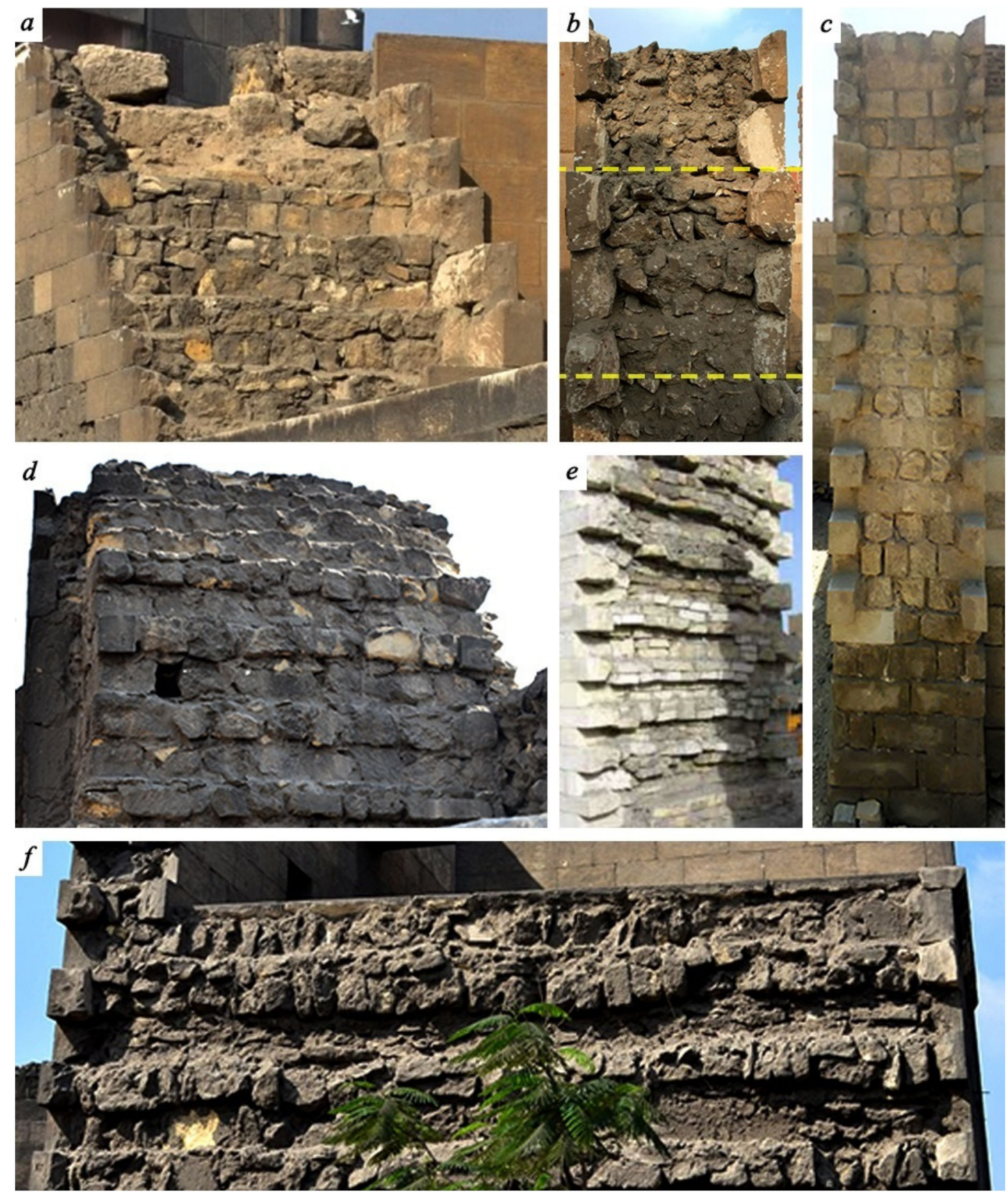

Figure 16. Different cross-sections of multiple-leaf stone masonry walls with the internal leaf built by successive layering of rubble stones and mortar bedding with horizontal courses: (a) Complex of Al-Sultan Hasan, (b) Complex of Sultan al-Ashraf Barsbay, (c) Qubba al-Amir Tarabay al-Sharifi, (d) and (f) perimeter wall of Bab Qaytbay; and (e) the aqueduct (Majra Al-'Uyun). 

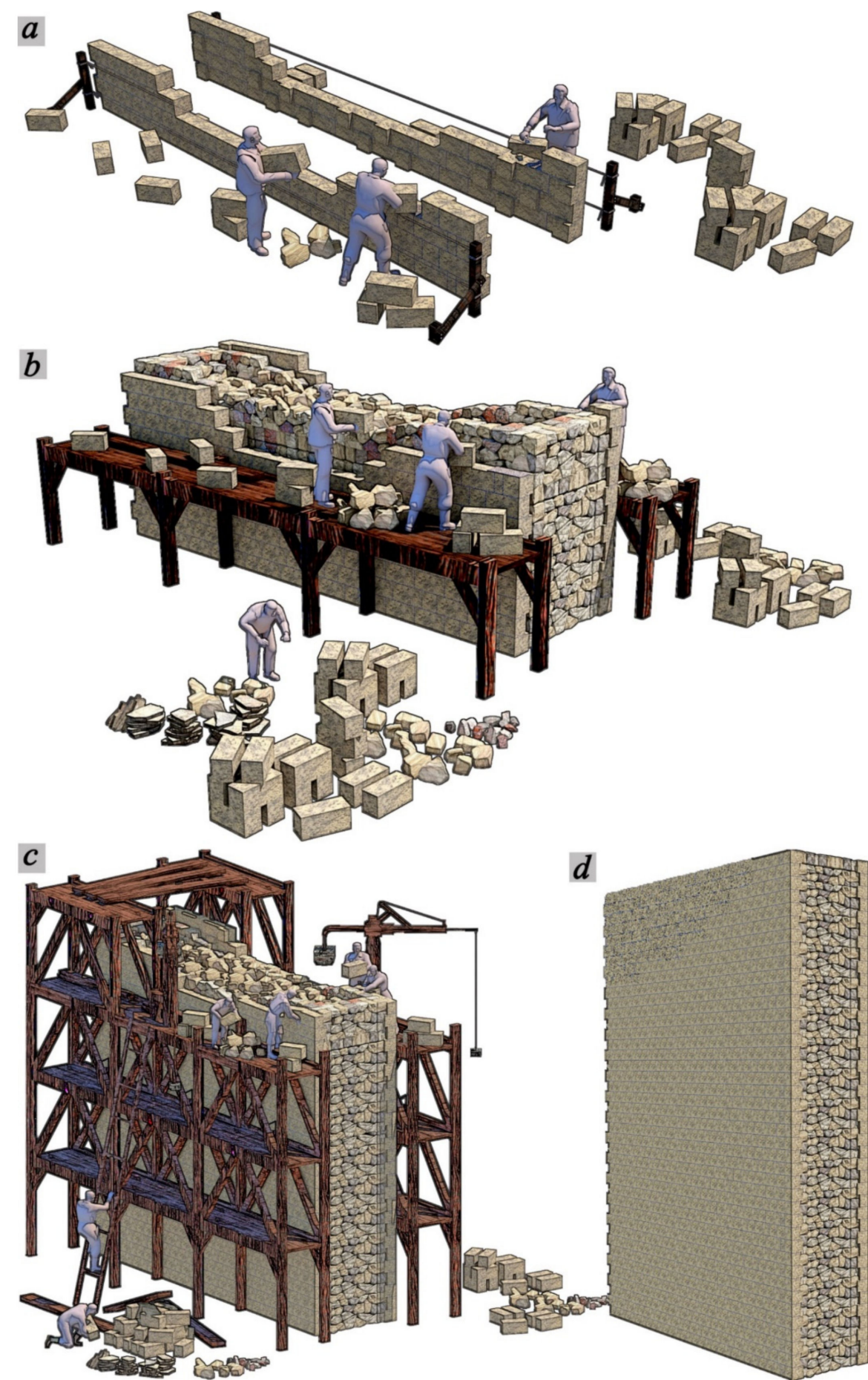

Figure 17. Construction hypothesis (III): (a) constructing the outer leaves up to a suitable height; (b) constructing the inner core layer by successive layering of rubble stones and mortar bedding with horizontal courses; (c) assembly of scaffolding erection for the construction of the upper parts; (d) the full tree-leaf stone masonry wall.

\section{Discussion}

The field study allowed concluding that the multi-leaf stone masonry walls varied in their geometrical characteristics, typologies, and construction techniques; consequently, according to their typology, they are characterized by different structural performance and load-transfer mechanisms. Classification of three types of multi-leaf stone-masonry walls was conducted (see Section 2.2.1) according to the complexity of the wall, the ratio between 
the thickness of the inner layer to the thickness of the outer layer, the composition of the inner core layer, and the type of bonding between the inner and outer layers.

In the case of a poor/incoherent core layer, the voids were indiscriminately diffused and the percentage of mortar was relatively high, in addition to the poor bonding between this inner layer and the outer layers due to the absence of any transversal bond elements (straight collar joints). Friction was the prevalent resistant mechanism, while cohesion within the internal leaf and adhesion between the leaves was scarce. In this case, the core layer resisted a very small portion of the applied vertical loads as most of the load was carried by the outer shells. Besides, the cohesionless core rubble infill exerted non-linear lateral pressure thrusting the outer leaves.

As a result of constructing the wall by this technique, the inner layer was nearly cohesionless and almost separated from the outer leaves; moreover, an indiscriminate diffusion of voids and relatively high percentages of mortar were formed. As a result, complex crack patterns, detachment, buckling, and expulsion of the outer leaves characterized the collapse mechanism. Accordingly, this construction method was commonly used in the case of a thin multi-leaf wall of low height (funerary, educational, and residential buildings).

In the case of defense structures, waterworks, military, and palatial and commercial buildings, another type of multiple-leaf masonry wall was utilized with an inner core layer characterized by high cohesion, good mechanical properties, and a considerable loadbearing capacity. The inner core layer had a low percentage of voids, and the percentage of mortar was relatively low, while the presence of rubble stones settled at a high percentage, corresponding to relatively high stiffness. In most of the external multi-leaf stone masonry walls, the outer leaves were arranged in a wide variety of ways to produce a satisfactory bond, and each arrangement could be identified by the pattern of headers and stretchers on the face of the wall.

The resistance of monolithic multi-leaf walls, with core infill layers characterized by poor connection between the inner and outer layers, mainly depended on the inner layer. Due to the absence of the transversally bound elements and shear keys, the bond between the leaves was weak, and the inner core layer could exert lateral load on both outer leaves, causing severe damage, detachment, and separation. Nevertheless, in many cases, the inner core layer was still upright, even after the potential collapse of the external layers, and safely resisted the applied vertical load due to its cohesive condition, which confirms that the overall structural behavior of the wall is mainly dependent on the performance of the core infill (see Figure 18).
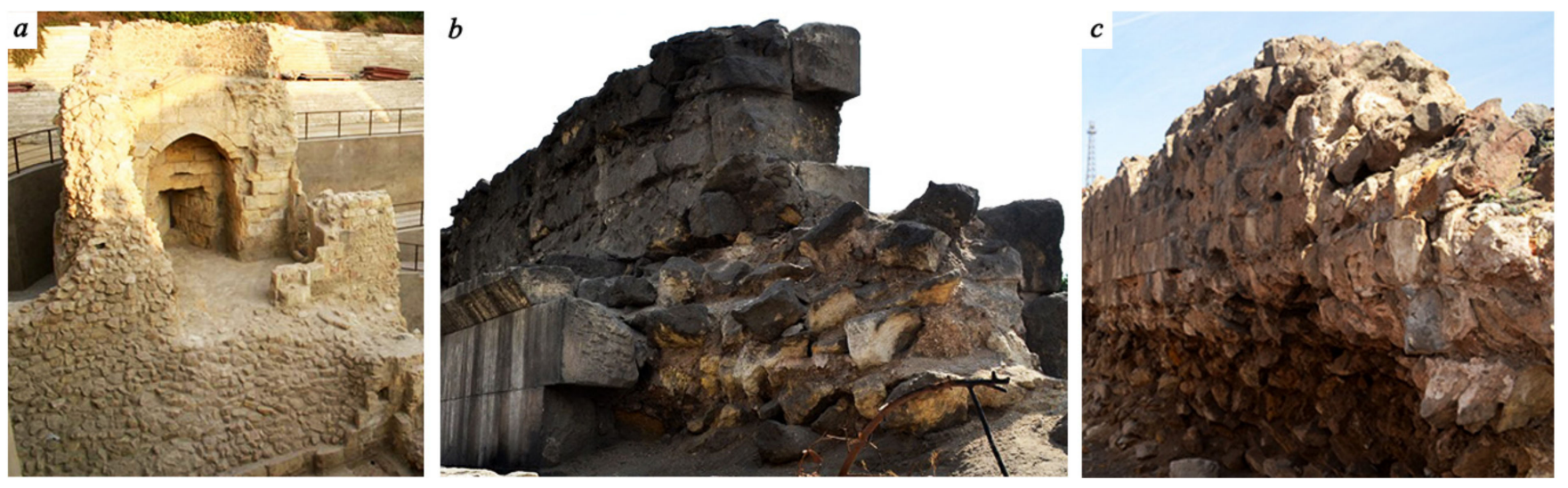

Figure 18. Examples of detachment and collapse of facing ashlar layers, exposing the inner core layer built of rubble stone masonry: (a) Bab al-Mahruq, (b) Bab Qaytbay, and (c) northeastern historic Cairo wall. 
To achieve effective cohesion between the inner and outer layers and ensure a homogeneous behavior of the wall, the mason usually provided a transversal bond by using long header stones (known as bonders). These transversal elements were extended to sufficient depth through the wall thickness in order to enhance the connectivity between the inner and external leaves and provide lateral reinforcement, which helped to resist lateral loads and overcome the brittle nature of rubble stone masonry. Accordingly, the three layers were able to homogeneously resist vertical and lateral applied loads. The different values of cohesion within the inner core layer and adhesion between the leaves, the possible presence of transverse elements, and different percentages of voids, are all parameters that can lead to relevant differences in the wall's global behavior.

In regards to the above, each type of defined multi-leaf stone masonry wall has its characteristic behavior under the external actions, which mainly depends on the mechanical properties and composition of the inner layer; the mechanical properties, type and arrangement of the stone units of the external layers; and the adopted connectivity between the inner and outer layers. This highlights the significance of considering these parameters when preparing mechanical models to investigate the global performance and detect the load-carrying capacity of this type of historic wall, and also when choosing the material and methods for the intervention and retrofitting. The appropriate numerical models for simulating the mechanical behavior of multi-leaf walls, as well as proposing an appropriate strengthening technique, mainly depend on an accurate investigation aimed at characterizing their geometry and construction techniques, together with the essential physicochemical and mechanical investigations of the utilized building materials.

\section{Conclusions}

The present research focused on the structural field survey of multiple-leaf stone masonry walls of historic buildings in a variety of historic areas in Egypt. By analyzing the obtained results of this fieldwork together with the available historical data, a general characterization of the common typologies of the transversal section of multiple-leaf stone masonry walls was performed. Moreover, various construction hypotheses of this type of historic construction were proposed, based mainly on the results obtained in the conducted field survey.

The survey results confirmed that the multiple-leaf masonry wall system was commonly used as vertical structural elements in almost all types of complex historical medieval structures in Egypt, i.e., religious, service, residential, fortification, irrigation, etc. These walls present different characteristics depending on their typologies and construction techniques, which gradually changed from multiple-leaf walls with a cohesionless internal core infill of weak mechanical resistance held by two separate external leaves to the fixed rubble-core masonry strongly bonded with the outer leaves, ensuring an overall composite performance of the wall. Usually, transversal tie elements of timber, marble, or stone were used to enhance the connectivity between the inner and external leaves and achieve an integrated composite mechanical performance of the wall.

Three main types of multiple-leaf stone masonry walls were identified according to the thickness and composition of the inner core layer. The monolithic core layer was usually utilized primarily in the historic military defense and hydraulic structures to enhance the overall stability of the wall against any potential lateral or impact loads. On the other hand, walls with relatively thin to thick core layers were used in religious, commercial, and residential buildings.

Since the multi-leaf stone masonry walls vary in their geometrical characteristics, typologies, morphologies, and construction materials, assessing their structural behavior essentially requires a detailed metric survey and comprehensive experimental investigation of the mechanical and physicochemical properties of their components. Additionally, the role of the core layer in carrying the applied external load has to be considered and accurately investigated, together with the prediction of the lateral pressure exerted by the 
cohesionless core infill on the outer layers. These investigations are a prerequisite for any intended strengthening and conservation practices.

Author Contributions: Conceptualization, O.A., D.A., E.k.M., A.T., and A.S.; methodology, O.A., D.A.; investigation, O.A., A.T., and A.S.; formal analysis, O.A., and E.k.M.; visualization, O.A.; writing—original draft preparation, O.A., and E.k.M.; writing—review and editing, O.A., D.A. All authors have read and agreed to the published version of the manuscript.

Funding: This research received no specific grant from any funding agency in the public, commercial, or not-for-profit sectors.

Data Availability Statement: The data presented in this study are available on request from the corresponding author.

Acknowledgments: We dedicate this article to Ioannis Liritzis, who has significantly contributed to the spread of Egyptian heritage conservation sciences. The authors are also grateful to Nikiforos Meimaroglou, Osama Talat, Eng. Amr Saleh, and Eng. Mustafa Bekhet for the collaboration and significant support.

Conflicts of Interest: The authors declare no conflict of interest.

\section{References}

1. Aldreghetti, I.; Baraldi, D.; Boscato, G.; Cecchi, A.; Massaria, L.; Pavlovic, M.; Reccia, E.; Tofani, I. Multi-Leaf Masonry Walls with Full, Damaged and Consolidated Infill: Experimental and Numerical Analyses. Key Eng. Mater. 2017, 747, 488-495. [CrossRef]

2. Egermann, R.; Frick, B.; Neuwald, C. Analytical and experimental approach to the load bearing behaviour of multiple leaf masonry. In Structural Repair and Maintenace of Historical Buildings III (STREMA); WIT Press: Southampton, UK; Boston, MA, USA, 1993.

3. Drysdale, R.G.; Hamid, A.A.; Baker, L.R. Masonry Structures: Behavior and Design; Leon, B.M.D., Zurite, P., Handy, S., Eds.; Prentice Hall: Hoboken, NJ, USA, 1999.

4. Drei, A.; Fontana, A. Influence of geometrical and material properties on multiple-leaf walls behaviour. WIT Trans. Built Environ. 2001, 55, 2001.

5. Feilden, B.M. Conservation of Historic Buildings; International Centre for the Study of the Preservation and the Restoration of Cultural Property (ICCROM): Rome, Italy, 2003.

6. Pulatsu, B.; Bretas, E.M.; Lourenco, P. Discrete element modeling of masonry structures: Validation and application. Earthq. Struct. 2016, 11, 563-582. [CrossRef]

7. Amer, O.; Aita, D.; Mohamed, E.K.; Torky, A.; Shawky, A. Experimental investigations and microstructural characterization for construction materials of historic multi-leaf stone-Masonry Walls. Heritage 2021, 4, 135. [CrossRef]

8. Pina-Henriques, J.; Lourenço, P.; Binda, L.; Anzani, A. Testing and modelling of multiple-leaf masonry walls under shear and compression. In Structural Analysis of Historical Constructions; Modena, C., Lourenço, P.B., Roca, P., Eds.; Taylor \& Francis Group: London, UK, 2004; pp. 299-310. ISBN 04-1536-379-9.

9. Pina-Henriques, J.L. Masonry under Compression: Failure Analysis and Long-Term Effects. Ph.D. Thesis, University of Minho, Braga, Portugal, 2005.

10. Da-Porto, F.; Valluzzi, M.R.; Modena, C. Investigations for the knowledge of multi-Ieaf stone masonry walls. In Proceedings of the First International Congress on Construction History, Madrid, Spain, 20-24 January 2003.

11. De Felice, G. Out-of-Plane Seismic Capacity of Masonry Depending on Wall Section Morphology. Int. J. Arch. Herit. 2011, 5, 466-482. [CrossRef]

12. Pulatsu, B.; Gencer, F.; Erdogmus, E. Study of the effect of construction techniques on the seismic capacity of ancient dry-joint masonry towers through DEM. Eur. J. Environ. Civ. Eng. 2020, 1-18. [CrossRef]

13. Vintzileou, E.; Tassios, T.P. Three-Leaf Stone Masonry Strengthened by Injecting Cement Grouts. J. Struct. Eng. 1995, 121, 848-856. [CrossRef]

14. Toumbakari, E.E. Lime-Pozzolan-Cement Grouts and Their Structural Effects on Composite Masonry Walls. Ph.D. Thesis, Katholieke Universiteit Leuven, Leuven, Belgium, 2002.

15. Valluzzi, M.R.; Da Porto, F.; Modena, C. Behavior and modeling of strengthened three-leaf stone masonry walls. Mater. Struct. 2004, 37, 184-192. [CrossRef]

16. Vintzileou, E. Grouting of Three-Leaf Masonry: Experimental Results and Prediction of Mechanical Properties. 2007, pp. 171190. Available online: https://www.researchgate.net/publication/242419246_GROUTING_OF_THREE-LEAF_MASONRY_ EXPERIMENTAL_RESULTS_AND_PREDICTION_OF_MECHANICAL_PROPERTIES (accessed on 16 August 2021).

17. Vintzileou, E.; Miltiadou-Fezans, A. Mechanical properties of three-leaf stone masonry grouted with ternary or hydraulic lime-based grouts. Eng. Struct. 2008, 30, 2265-2276. [CrossRef]

18. Mazzon, N. Influence of Grout Injection on the Dynamic Behaviour of Stone Masonry Buildings. Ph.D. Thesis, University of Padova, Padova, Italy, 2010. 
19. Valluzzi, M.R.; da Porto, F.; Modena, C. Behaviour of multi-leaf stone masonry walls strengthened by different intervention techniques. In Historical Constructions: Possibilities of Numerical and Experimental Techniques; Lourenço, P., Roca, P., Eds.; University of Minho: Guimarães, Portugal, 2001; pp. 1023-1032.

20. Anzani, A.; Binda, L.; Fontana, A.; Henriques, J.P. An experimental investigation on multiple-leaf stone masonry. In Proceedings of the 13th International Brick and Block Masonry Conference, Amsterdam, The Netherlands, 4-7 July 2004.

21. Toumbakari, E.; Gemert, D.V.; Tassios, T.; Vintzileou, E. Experimental investigation and analytical modeling of the effect of injection grouts on the structural behaviour of three-Ieaf masonry walls. In Structural Analysis of Historical Constructions; Modena, C., Lourenço, P.B., Roca, P., Eds.; Taylor \& Francis Group: London, UK, 2005; pp. 707-717.

22. Valluzzi, M.R.; Mazzon, N.; Munari, M.; Casarin, F.; Modena, C. Effectiveness of Injections Evaluated by Sonic Tests on Reduced Scale Multi-Leaf Masonry Building Subjected to Seismic Actions. 2009, pp. 2-7. Available online: https: / / www.researchgate.net/publication/237761734_Effectiveness_of_injections_evaluated_by_sonic_tests_on_reduced_scale_ multi-leaf_masonry_building_subjected_to_seismic_actions (accessed on 16 August 2021).

23. Van Gemert, D.; Ignoul, S.; Brosens, K.; Toumbakari, E.-E. Consolidation and Strengthening of Historical Masonry by Means of Mineral Grouts: Grout Development. Restor. Build. Monum. 2015, 21, 29-45. [CrossRef]

24. Bhandari, S.; Shrestha, J.K.; Pradhan, S. In-plane capacity of multi-leaf stone masonry walls. In Proceedings of the IOE Graduate Conference, Kirtipur, Nepal, May 2019.

25. Amer, O.; Abdel-Aty, Y.; Abdel-Hady, M.; Aita, D.; Torky, A.; Hussein, Y. Multiscientific-based approach to diagnosis and characterization of historic stone-masonry walls: The mausoleum of al-imam al-shafi'i, cairo (egypt). Mediterr. Archaeol. Archaeom. 2020, 20, 67-82.

26. Creswell, K. The Muslim Architecture of Egypt; Hacker Art Books; Clarendon Press: New York, NY, USA, 1978 ; Volume 1.

27. Behrens-Abouseif, D. Topography and Architecture of the North-Eastern Suburbs of Cairo in the Circassian Mamluk Period. Master's Thesis, American University in Cairo (A.U.C.), New Cairo, Egypt, 1980.

28. Behrens-Abouseif, D.; Fernandes, L. Sufi Architecture in Early Ottoman Cairo. In Annales Islamologiques; Institut Français D’archéologie Orientale: Cairo, Egypt, 1984; Volume 20, pp. 103-114.

29. Behrens-Abouseif, D. Change in Function and Form of Mamluk Religious Institutions. In Annales Islamologiques; Institut Français D'archéologie Orientale: Cairo, Egypt, 1985; Volume 21, pp. 73-93.

30. Allen, T. A Classical Revival in Islamic Architecture; Ludwig Reichert: Wiesbaden, Germany, 1986.

31. Hoag, J. Islamic Architecture; Rizzoli: New York, NY, USA, 1987.

32. Behrens-Abouseif, D. The Takiyyat Ibrahim al-Kulshani in Cairo. In Muqarnas; Brill: Leiden, The Netherlands, 1988; Volume 5, pp. 43-60.

33. Behrens-Abouseif, D. Islamic Architecture in Cairo: An Introduction; American University in Cairo (A.U.C.) Press: Cairo, Egypt, 1989.

34. OICC. Organization of Islamic Capitals and Cities, Principles of Architectural Design and Urban Planning During Different Islamic Eras: Analytical Study for Cairo City, Jeddah, Saudi Arabia: Markaz al-Dirāsāt al-Takhțìtīyah wa-al-Mì̄Mārīyah; Center for Revival of Islamic Architectural Heritage: Cairo, Egypt, 1992.

35. Mal, H. Domes in Islamic Architecture "al-Quba al-Madfan", Its Evolution Till the end of Mamluk Period, 1st ed.; Al-Thaqafa al-Deenya Liberary: Cairo, Egypt, 1993. (In Arabic)

36. Jarrar, S.; Riedlmayer, A.; Jeffrey, B.S. Resources for the Study of Islamic Architecture; Aga Khan Program for Islamic Architecture: Cambridge, MA, USA, 1994.

37. Hillenbrand, R. Islamic Architecture: Form, Function and Meaning; Edinburgh University Press: Edinburgh, UK, 1994.

38. Antoniou, J. Historic Cairo A Walk through the Islamic City; Third Printing; The American University in Cairo Press (A.U.C): Cairo, Egypt, 2002.

39. Williams, C. Islamic Monuments in Cairo. In The Practical Guide, 5th ed.; The American University in Cairo Press (A.U.C): Cairo, Egypt, 2002.

40. Warner, N. The Monuments of Historic Cairo, a Map and Descriptive Catalogue, 132; American University in Cairo Press (A.U.C): Cairo, Egypt, 2005.

41. Yeomans, R. The Art and Architecture of Islamic Cairo, 1st ed.; Garnet Publishing: Cairo, Egypt, 2006.

42. Behrens-Abouseif, D. Cairo of the Mamluks: A History of Architecture and Its Culture; I.B. Tauris: London, UK, 2007.

43. Binda, L.; Cardani, G.; Saisi, A. A classification of structures and masonries for the adequate choice of repair. In International RILEM Workshop on Repair Mortars for Historic Masonry; RILEM, International Union of Laboratories and Experts in Construction Materials, Systems and Structures: Delft, The Netherlands, 2005; pp. 20-34.

44. Amer, O. Experimental and Analytical Studies on Structural Behavior of Multiple-Leaf Masonry Walls under Loads and Biological Factors, and the Appropriate Restoration Techniques with Application on Chosen Historical Islamic Buildings Biologically Affec. Master's Thesis, Conservation Department, Faculty of Archaeology, Cairo University, Cairo, Egypt, 2018.

45. Egermann, R.; Neuwald-Burg, C. Assessment of the load bearing behaviour of historic multiple leaf masonry walls. In Proceedings of the 10th International Brick/Block Masonry Conference (IBMAC), Calgary, AB, Canada, 5-7 July 1994; pp. 1603-1612.

46. Binda, L.; Fontana, A.; Anti, L. Load transfer in multiple leaf masonry walls. In Proceedings of the 9th International Brick/Block Masonry Conference, Berlin, Germany, 13-16 October 1991. 
47. Mohamed, E.K.; Khalil, E. Innovative solution for the repair of hydraulic structures (regulators). Water Sci. 2018, 32, 179-191. [CrossRef]

48. Dalgleish, G.S. The Sanayta lock and bride-regulator (Including plate at back of volume). In Minutes of the Proceedings of the Institution of Civil Engineers; ICE Publishing: Washington, DC, USA, 1901. 